\title{
The role of IGF1 in the in vivo production of bovine embryos from superovulated donors
}

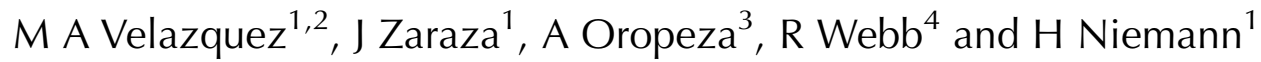 \\ ${ }^{1}$ Department of Biotechnology, Institute of Farm Animal Genetics, Friedrich-Loeffler-Institute (FLI), Höltystrasse 10, \\ 31535 Neustadt-Mariensee, Germany, ${ }^{2}$ Escuela Superior de Ciencias Agropecuarias, Universidad Autónoma de \\ Campeche, Calle $53 \mathrm{~s} / \mathrm{n}$, C.P. 24350 Escárcega, Campeche, México, ${ }^{3}$ Departamento de Genética y Reproducción \\ Animal, Decanato de Ciencias Veterinarias, Universidad Centroccidental 'Lisandro Alvarado' (UCLA), Apartado 400, \\ Barquisimeto 3001, Venezuela and ${ }^{4}$ Division of Animal Sciences, School of Biosciences, University of Nottingham, \\ Sutton Bonington Campus, Loughborough, Leicestershire LE12 5RD, UK
}

Correspondence should be addressed to M A Velazquez; Email: lestaurus_18@hotmail.com

H Niemann; Email: heiner.niemann@fli.bund.de

\begin{abstract}
IGF1 plays an important role in bovine follicular growth, acquisition of oocyte competence and embryo viability. Current data also indicate a critical role for IGF1 in both the ovarian response and the embryo yield following the superovulatory treatments. IGF1 can have either positive or negative effects on embryo viability which is related to the concentration of IGF1 induced by superovulation treatment. These effects impact either on oocyte competence or directly on the embryo. Concentrations in the physiological range appear to result in the production of higher quality embryos, mainly due to the mitogenic and the anti-apoptotic activities of IGF1. However, high superovulatory responses are associated with decreased embryo viability and a concomitant increase in apoptosis. Studies in mice suggest that this increase in apoptosis is related to the downregulation of the IGF1 receptor in the embryo associated with high IGF1 concentrations. Strategies capable of controlling the IGF1 concentrations could be one approach to improve superovulation responses. A range of possible approaches for research within the IGF system in gonadotrophin-stimulated cattle is discussed in this review, including the possible use of superovulated female cattle as an alternative animal experimental model for research on reproductive disorders in humans associated with abnormal IGF1 concentrations.
\end{abstract}

Reproduction (2009) 137 161-180

\section{Introduction}

Superovulatory treatments are being used worldwide for the production of bovine embryos in multiple ovulation and embryo transfer (MOET) programmes. The goal of superovulatory treatments in the cattle industry is the production of a large number of viable embryos capable of establishing and maintaining pregnancy after transfer and delivering healthy offspring. During superovulation, the quality of the embryo might be affected either through effects on the oocyte during follicular growth (Sirard et al. 2006) or directly during embryo development while in the oviduct and/or uterus (Barnes 2000, Greve \& Callesen 2001, Killian 2004). Several growth factors have been shown to regulate follicular growth and embryo development, including insulin-like growth factor 1 (IGF1; Díaz-Cueto \& Gerton 2001, Hardy \& Spanos 2002, Diskin et al. 2003, Fortune 2003, Wolf et al. 2003, Webb et al. 2004). IGF1 plays an essential role in mammalian reproduction, as shown by the impaired ovarian activity and embryo development in gene knockout mouse models (Liu et al. 1993, Baker et al. 1996, Zhou et al. 1997, Kadakia et al. 2001).

The effects of IGF1 on ovarian follicular growth and preimplantation embryo development of non-superovulated domestic ruminants have been the subject of a number of reviews (Kaye et al. 1992, Simmen et al. 1993, Spicer \& Echternkamp 1995, Wathes et al. 1998, 2003, Watson et al. 1999, Lucy 2000, Kaiser et al. 2001, Khamsi et al. 2001 a, Gong 2002, Mihm \& Austin 2002, Zulu etal. 2002, Mazerbourg et al. 2003, Sinclair et al. 2003, Webb et al. 2003, Beg \& Ginther 2006, Webb \& Campbell 2007). Growing evidence has demonstrated the importance of IGF1 for the success of superovulatory treatments (Herrler et al. 1994, O'Callaghan et al. 2000, Cushman et al. 2001, Velazquez et al. 2005). For instance, oocyte quality and embryo viability have been associated with IGF1 concentrations in domestic ruminants undergoing superovulation $\left(\mathrm{O}^{\prime}\right.$ Callaghan et al. 2000, Velazquez etal. 2005). Moreover, treatments capable of increasing 
IGF1 concentrations in ovarian follicular fluid of superstimulated donors were related to increased numbers of viable embryos in vivo (Herrler et al. 1994, Cushman et al. 2001).

In this review, we emphasize the link between both local and peripheral IGF1 concentrations and bovine embryo production in vivo by superovulation, and propose new directions for future research, including the possible use of superovulated cattle as an alternative model to investigate reproductive disorders in humans associated with IGF1 concentrations outside the physiological range.

\section{The IGF superfamily}

IGF1 and IGF2 were first identified by Salmon \& Daughaday (1956, 1957), and designated 'sulphation factor' due to their ability to incorporate sulphate into rat cartilage in vitro. They were also known as nonsuppressible insulin-like activity (NSILA) I and II (Froesch et al. 1963). A decade later, the terms sulphation factor and NSILA were replaced by the term 'somatomedin' (Daughaday et al. 1972) and subsequently they were renamed 'IGFs 1 and 2 ' due to their structural similarity with insulin and their growth-promoting activities (Rinderknecht \& Humbel 1976a, 1976b).

IGF1 is one of two ligands of the IGF family (Hwa et al. 1999, Spicer 2004) and is a small peptide consisting of 70 amino acids with a molecular mass of $7649 \mathrm{kDa}$ (Laron 2001). The established components of the IGF system also include two receptors, six high-affinity IGFbinding proteins (IGFBPs) and IGFBP proteases (Giudice 1995, Hwa et al. 1999, Spicer 2004). Furthermore, another group of low-affinity binding proteins, known as IGFBP-related proteins (IGFBP-rPs), belongs to the IGF family. However, no final nomenclature has been agreed for these proteins, as several research groups have identified the same protein and each group has used a different nomenclature (Hwa et al. 1999, Rosenfeld et al.
2001). Potential receptors for IGFBP(s) and IGFBP-rP(s) have also been reported to be part of the IGF family (Hwa et al. 1999; Table 1). Due to similarities in structure and sharing intracellular signalling cascades with other members of the IGF system, insulin, its receptor and a hybrid insulin/IGF receptor are also considered to be part of the IGF superfamily (Jones \& Clemmons 1995, Monget \& Martin 1997, McCusker 1998, Poretsky et al. 1999, Butler \& Le Roith 2001, Juul 2003).

\section{Brief overview on the role of IGF1 in non-superovulated cattle}

\section{Effects of IGF1 in bovine ovarian follicular growth and oocyte quality}

The IGF1 receptor has been localized in bovine oocytes, cumulus cells and in both granulosa and theca cells (Yoshida et al. 1998, Perks et al. 1999, Armstrong et al. 2001, Schams et al. 2002, Nuttinck et al. 2004, Sudo et al. 2007). In vitro studies have shown that IGF1 synergizes with $\mathrm{FSH}$ to regulate the aromatase activity of granulosa cells (Spicer et al. 2002). Accordingly, a positive association was found between supplementation in vitro of the media with human recombinant IGF1 $(100-400 \mathrm{ng} / \mathrm{ml})$ and oestradiol production by bovine ovarian cells (Spicer et al. 1993, 2002, Yang \& Rajamahendran 1998). Other in vitro effects of IGF1 include enhanced secretion of follistatin, inhibin-A, activin-A in granulosa cells (Glister et al. 2001, 2003, 2006), increased androstenedione production from theca cells (Stewart et al. 1995) and protection from apoptosis in oocytes and granulosa cells (Quirk et al. 2000, Yang \& Rajamahendran 2000, Wasielak \& Bogacki 2007). Several studies also observed that cumulus-oocyte complexes treated with IGF1, alone or in combination with either epidermal growth factor or angiotensin II, showed increased cumulus expansion,

Table 1 The insulin-like growth factor superfamily.

\begin{tabular}{|c|c|c|}
\hline Ligands & \multicolumn{2}{|c|}{ Receptors } \\
\hline $\begin{array}{l}\text { IGF1 } \\
\text { IGF2 }\end{array}$ & \multicolumn{2}{|c|}{$\begin{array}{l}\text { Type } 1 \text { IGF receptor } \\
\text { Type } 2 \text { IGF or IGF 2/mannose-6-phosphate (IGF2/M6P) receptor }\end{array}$} \\
\hline Binding proteins & Binding protein proteases & Binding protein-related proteins \\
\hline $\begin{array}{l}\text { IGFBP1 } \\
\text { IGFBP2 } \\
\text { IGFBP3 } \\
\text { IGFBP4 } \\
\text { IGFBP5 } \\
\text { IGFBP6 }\end{array}$ & $\begin{array}{l}\text { IGFBP2 proteases } \\
\text { IGFBP3 proteases } \\
\text { IGFBP4 proteases } \\
\text { IGFBP5 proteases }\end{array}$ & $\begin{array}{l}\text { IGFBP-rP1 }{ }^{\mathrm{a}} \text { (IGFBP7/MAC25/TAF/PSF) } \\
\text { IGFBP-rP2 }{ }^{\mathrm{a}}(\mathrm{CTGF}) \\
\text { IGFBP-rP3 }{ }^{\mathrm{a}}(\mathrm{NovH}) \\
\text { IGFBP-rP4 }{ }^{\mathrm{a}}(\mathrm{CYR} 61) \\
\text { IGFBP-rP5 }{ }^{\mathrm{a}}(\mathrm{L} 56 / \mathrm{HTRA} 1) \\
\text { IGFBP-rP6 }{ }^{\mathrm{a}} \text { (ESM1) }\end{array}$ \\
\hline & $\begin{array}{l}\text { Potential receptors } \\
\text { IGFBP(s) } \\
\text { IGFBP-rP(s) }\end{array}$ & $\begin{array}{l}\text { IGFBP-rP7 a(rCOP-1/WISP2/CTGF-L) } \\
\text { IGFBP-rP8 a(ELM1/WISP1) } \\
\text { IGFBP-rP9 a(WISP3) }\end{array}$ \\
\hline
\end{tabular}

In italics are the components of the established IGF system. Based on Giudice (1995), Hwa et al. (1999), Monget \& Bondy (2000) and Spicer (2004). ${ }^{\mathrm{a}}$ Other designations. 
improved nuclear maturation rate and enhanced pyruvate metabolism (Lorenzo et al. 1994, 1995, Idris Anas et al. 1998, Iga et al. 1998, Rieger et al. 1998, Sakaguchi et al. 2000, 2002, Stefanello et al. 2006). The effect of IGF1 on bovine ovarian follicle growth also depends on various factors, such as follicular stage, cell cycle and treatment dose. For instance, $20 \mathrm{ng} / \mathrm{ml}$ human recombinant IGF1 and $1 \mathrm{ng} / \mathrm{ml}$ Long R3 IGF1, which have a 1000-fold reduced affinity for IGFBPs (Francis et al. 1992), promote antrum formation and increase oocyte diameter in preantral follicles (Gutierrez et al. 2000, Itoh et al. 2002). By contrast, 5-50 ng/ml Long R3 IGF1 and $1000 \mathrm{ng} / \mathrm{ml}$ human recombinant IGF1 induced detrimental effects on oocyte morphology, size and number of granulosa cell layers in the same category of follicles (McCaffery et al. 2000, Thomas et al. 2007). In small antral follicles, $1000 \mathrm{ng} / \mathrm{ml}$ human recombinant IGF1 can increase follicle diameter (165-215 $\mu \mathrm{m})$, but not in medium-sized $(216-280 \mu \mathrm{m})$ and large antral follicles (281-380 $\mu \mathrm{m}$; Walters et al. 2006). In addition, the protective effects of IGF1 against apoptosis in granulosa cells are exerted only with unperturbed progression from the $\mathrm{G}_{1}$ - to S-phase of the cell cycle (Hu et al. 2004). Collectively, these data indicate that keeping IGF1 concentrations within a normal physiological range is required for proper ovarian follicular function.

The biological significance of IGF1 in ovarian physiology was further demonstrated in an autotransplanted ovarian sheep model in which the ovary is relocated to a site under the skin of the neck. Direct infusion of an IGF1 analogue for $12 \mathrm{~h}(80-90 \mu \mathrm{g} / \mathrm{h})$ into the ovarian artery of the conscious animal significantly enhanced the secretion of oestradiol (Scaramuzzi et al. 1999). Spicer et al. (2000) infused IGF1 concentrations closer to the physiological range with osmotic minipumps at a rate of $150 \mathrm{ng} / \mathrm{ml}$ per hour for 7 days directly into the ovary. This treatment increased the concentrations of oestradiol and IGF1 in the follicular fluid of small follicles $(2-5 \mathrm{~mm})$. Surprisingly, the follicle diameter was increased by IGF1 infusion only in the largest follicle, even though follicular fluid IGF1 concentrations were not altered. This discrepancy was attributed to an increased clearance of IGF1 in large follicles due to lower levels of IGFBPs when compared with small follicles (Spicer et al. 2000). IGFBPs play a pivotal role in the control of IGF1 bioavailability. IGFBPs inhibit the effects of IGF1 possibly by sequestering extracellular IGF1 and thereby limiting access to cell surface receptors. IGFBPs also potentiate IGF1 actions by prolonging its half-life (via protection against degradation), acting as a reservoir to sustain controlled delivery to target cells and facilitating transport from the peripheral circulation to target tissues (Clemmons 1998, Baxter 2000, Firth \& Baxter 2002). As evidenced in several studies, high levels of IGFBP2, 4 and 5 were found in bovine follicular fluid from atretic subordinate follicles compared with dominant healthy follicles (Table 2). These three IGFBPs correlate negatively with follicular diameter during antral follicle development (Austin et al. 2001). IGFBP3 is the major circulatory

Table 2 Changes of insulin-like growth factor binding protein 2, 3, 4 and 5 (IGFBPs) and their proteolytic activity in bovine follicular fluid during ovarian follicular antrum development and atresia.

\begin{tabular}{|c|c|c|c|c|c|c|c|c|c|c|c|c|}
\hline \multicolumn{2}{|c|}{ Follicular status } & \multirow[b]{2}{*}{$\begin{array}{l}\text { Sampling } \\
\text { frequency }\end{array}$} & \multirow[b]{2}{*}{$\begin{array}{c}\text { Contrasting } \\
\text { follicle }^{\mathrm{a}}(\mathrm{mm})\end{array}$} & \multicolumn{4}{|c|}{ FF changes of IGFBP } & \multicolumn{4}{|c|}{$\begin{array}{c}\text { Proteolytic activity in FF of } \\
\text { IGFBP }\end{array}$} & \multirow[b]{2}{*}{ References } \\
\hline Category & $\begin{array}{l}\text { Diameter } \\
(\mathrm{mm})\end{array}$ & & & 2 & 3 & 4 & 5 & 2 & 3 & 4 & 5 & \\
\hline \multirow[t]{14}{*}{ S-DF } & $(\sim 13.5)$ & Single & $\operatorname{SubF}(\sim 5-12)$ & $\downarrow$ & $\uparrow$ & - & - & - & - & - & - & Echternkamp et al. (1994) \\
\hline & (?) & Multiple & SubF (?) & $\downarrow$ & $\uparrow$ & $\downarrow$ & $\downarrow$ & - & - & - & - & de la Sota et al. (1996) \\
\hline & $(\sim 11-17)$ & Multiple & $\operatorname{SubF}(<9)$ & $\downarrow$ & $\uparrow$ & - & - & - & - & - & - & Stewart et al. (1996) \\
\hline & (?) & Multiple & SubF $(\leq 5)$ & - & $\uparrow$ & - & - & - & - & - & - & Funston et al. (1996) \\
\hline & $(\geq 8.5)$ & Multiple & SubF ( 4-8.5) & $\downarrow$ & $\uparrow$ & $\downarrow$ & $\downarrow$ & - & - & - & - & Austin et al. (2001) \\
\hline & $(\sim 11-16.5)$ & Multiple & SubF ( 7 to 8.5$)$ & - & - & $\uparrow$ & $\uparrow$ & - & - & - & - & Rhodes et al. (2001) \\
\hline & $(\sim 12)$ & Single & SubF $(\sim 9)$ & $\downarrow$ & $\uparrow$ & $\downarrow$ & $\downarrow$ & - & - & $\uparrow$ & - & Rivera \& Fortune (2001) \\
\hline & $(\sim 19.5)$ & Single & SubF ( 1-8.5) & $\downarrow$ & $\uparrow$ & $\downarrow$ & $\downarrow$ & $\uparrow$ & $\mathfrak{1}$ & $\uparrow$ & $\uparrow$ & Spicer et al. (2001) \\
\hline & $(\sim 16)$ & Single & SubF ( 9-17) & $\downarrow$ & $\downarrow$ & $\uparrow$ & $\uparrow$ & - & - & - & - & Kojima et al. (2003) \\
\hline & $(\sim 16)$ & Single & Atretic ( 9-12.5) & $\downarrow$ & $\downarrow$ & $\downarrow$ & $\downarrow$ & - & - & - & - & Kojima et al. (2003) \\
\hline & $(\geq 8.5)$ & Multiple & $\operatorname{SubF}(\sim 7-8)$ & $\downarrow$ & $\uparrow$ & $\downarrow$ & $\downarrow$ & - & - & $\uparrow$ & $\uparrow$ & Rivera \& Fortune (2003) \\
\hline & $(\sim 11-14)$ & Single & SubF $(\sim 4-8)$ & $\downarrow$ & $\uparrow$ & $\downarrow$ & $\downarrow$ & - & - & - & - & Nicholas et al. (2005) \\
\hline & $(\sim 17-19)$ & Multiple & SubF ( 7-8.5) & $\downarrow$ & $\uparrow$ & $\downarrow$ & $\downarrow$ & - & - & - & - & Santiago et al. (2005) \\
\hline & $(\sim 12)$ & Multiple & SubF $(\sim 6-8$ & $\downarrow$ & $\uparrow$ & $\downarrow$ & $\downarrow$ & - & - & - & - & Canty et al. (2006) \\
\hline \multirow[t]{3}{*}{ Co-DF } & $(\sim \geq 17)$ & Multiple & $\operatorname{SubF}(\sim<13.5)$ & $\downarrow$ & $\uparrow$ & - & - & - & - & - & - & Echternkamp et al. (1994) \\
\hline & $(\sim 10.5-12)$ & Single & SubF ( 9) & $\downarrow$ & $\uparrow$ & $\downarrow$ & $\downarrow$ & - & - & $\uparrow$ & - & Rivera \& Fortune (2001) \\
\hline & $(\sim 9)$ & Single & SubF ( 7-8) & $\downarrow$ & $\uparrow$ & $\downarrow$ & $\downarrow$ & - & - & $\uparrow$ & $\uparrow$ & Rivera \& Fortune (2003) \\
\hline Healthy $^{c}$ & $(3-5)$ & Single & Atretic(4-5) & $\downarrow$ & $\uparrow$ & $\downarrow$ & $\downarrow$ & - & - & - & - & Irving-Rodgers et al. (2003) \\
\hline
\end{tabular}

FF, follicular fluid; ?, not reported; S-DF, single dominant follicle; Co-DF, co-dominant follicle; SubF, subordinate follicle; $\uparrow$, levels increase; $\downarrow$, levels decrease; $\uparrow$, levels remain relatively constant; -, not analyzed or not clearly identified.

${ }^{a}$ Makes reference to the category of ovarian follicle(s) used for comparison in the experiment. ${ }^{b} \mathrm{Co}$-dominant follicles were induced with FSH treatment. 'Follicles with an intact membrana granulosa with a few pyknotic nuclei. 
carrier of IGF1 and is predominantly present in dominant follicles (Gradela et al. 1998, Nicholas et al. 2002). The complexity of the IGF system is further illustrated by specific IGFBP proteases described in several species including cattle (Spicer et al. 2004), which enhance the amount of free IGF1 within a follicle despite synthesis of IGFBPs (Mihm \& Austin 2002).

The enhanced oestradiol production following exogenous treatment of IGF1 illustrates the importance of endocrine IGF1 for ovarian function in domestic ruminants. The endocrine function of IGF1 is supported by experiments where immunization against $\mathrm{GH}$ releasing factor significantly reduced serum and intrafollicular concentrations of IGF1 in both cows (Kirby et al. 1993) and heifers (Cohick et al. 1996). However, the major IGF ligand produced in bovine ovaries is IGF2. It is expressed mainly in theca cells from the time of antrum development up to ovulatory-sized follicles (Armstrong et al. 2000). Expression in granulosa cells is either low (Schams et al. 2002) or absent (Armstrong et al. 2000), and its effects on bovine theca and granulosa cell steroidogenesis are mediated via the IGF1 receptor (Spicer et al. 2004, Spicer \& Aad 2007). Bovine IGF1 of extra-ovarian origin also has an important role in the transition from 2 to $5 \mathrm{~mm}$ diameter follicles to the $\mathrm{FSH}$ dependent development (>5 mm; Monget \& Bondy 2000). Indeed, treatment with recombinant bovine somatotrophin (bST) increased the number of follicles 2-5 mm in diameter, with a parallel increment in systemic IGF1 (Gong et al. 1991, 1993a, 1997, De la Sota et al. 1993). A possible mechanism underlying these observations might be the important function of IGF1 in increasing the sensitivity of small antral follicles to FSH action (Mazerbourg et al. 2003). The activity of IGF1 in follicular growth and steroidogenesis is critical in the selection of the dominant follicle in non-superovulated cattle (Beg \& Ginther 2006). Accordingly, the enhanced follicular development observed in cows selected for twin ovulations has been associated with greater IGF1 concentrations in blood and follicular fluid when compared with non-selected control cattle (Echternkamp et al. 1990, 2004). However, IGF1 concentrations together with other key metabolic hormones such as insulin are crucial for oestrous cyclicity in both lactating and non-lactating cattle (Garnsworthy et al. 2008, Velazquez et al. 2008a).

\section{Effects of IGF1 in bovine preimplantation embryo development}

The effects of IGF1 on early bovine embryos are mediated by its own receptor (Matsui et al. 1997). Several studies have found IGF1 mRNA in the bovine uterus (Geisert et al. 1991, Robinson et al. 2000, Meikle et al. 2001, Pershing et al. 2002), but not in the oviducts (Viuff et al. 1995, Xia et al. 1996, Pershing et al. 2002). However, other studies have reported that bovine oviductal cells produce IGF1 (Schmidt et al. 1994, Makarevich \& Sirotkin 1997, Winger et al. 1997, Pushpakumara et al. 2002). Hence, during the preimplantation period, endocrine and/or paracrine IGF1 may act directly on the embryo or indirectly via modulation of the oviductal and uterine secretions (Wathes et al. 1998, 2003, Velazquez et al. 2008a).

Direct effects of IGF1 on in vivo embryo viability in non-superovulated cattle have not yet been demonstrated. A positive effect of IGF1 on embryogenesis has been proposed by the studies in which improved bovine embryo production in vitro was found after IGF1 supplementation in the concentrations ranging from 10 to $200 \mathrm{ng} / \mathrm{ml}$ (Herrler et al. 1992, Matsui et al. 1997, Palma et al. 1997, Prelle et al. 2001, Byrne et al. 2002a, Makarevich \& Markkula 2002, Moreira et al. 2002a, Sirisathien \& Brackett 2003, Sirisathien et al. 2003, Lima et al. 2006, Stefanello et al. 2006, Velazquez et al. 2008b). The beneficial effects of IGF1 were visible as decreased apoptosis and increased total cell number in preimplantation embryos (Byrne et al. 2002b, Makarevich \& Markkula 2002). In bovine preimplantation embryos IGF1 stimulates cell proliferation through the mitogen-activated protein kinase signalling cascade, while the anti-apoptotic actions are mediated via the phosphatidylinositol 3-kinase (P13K)/AKT1 (also known as protein kinase B) pathway (Jousan \& Hansen 2007, Jousan et al. 2008). IGF1 blocked the induction of apoptosis in bovine embryos exposed to heat shock in vitro, suggesting a protective role against embryonic stressors (Jousan \& Hansen 2004, 2007, Jousan et al. 2008). Similarly, IGF1 improved embryo development, cell proliferation and embryo diameter in rabbit embryos exposed to uv radiation (Herrler et al. 1998). In mouse embryos, the detrimental effects of oxidative stress induced by hydrogen peroxide could be alleviated by the addition of IGF1 to the culture medium (Kurzawa et al. 2002, 2004). Rodent embryos were protected against specific apoptosis inducing factors such as tumour necrosis factor- $\alpha$, camptothecin or actinomycin $D$ by supplementation of the culture media with IGF1 (Byrne et al. 2002b, Fabian et al. 2004, Glabowski et al. 2005). Pregnancy rates were increased after transfer of in vitro-produced cattle embryos treated with IGF1, showing a substantial improvement of the embryonic developmental capacity (Block et al. 2003, Block 2007, Block \& Hansen 2007). However, IGF1 cannot overcome the negative effects following cryopreservation (Willemsen et al. 1995, Hernandez-Fonseca et al. 2002). It should also be noted that some authors did not find the beneficial effects of IGF1 treatment during in vitro production of bovine embryos (Flood et al. 1993, Lee \& Fukui 1995, Quetglas et al. 2001, Hernandez-Fonseca et al. 2002, Block et al. 2008). Differences in culture media, protein supplementation and the concentrations of IGF1 utilised might explain these contrasting results. 
Recent data indicate that IGF1 affects the physiology of the bovine embryo by altering the relative abundance of developmentally important mRNA transcripts, including desmocollin II, Na/K-ATPase, BAX, IGF1 receptor, IGFBP3 and heat shock protein 70 . Furthermore, these gene expression changes may occur without detectable changes in cell number, apoptosis and the ratio between inner cell mass and trophectoderm cells (Block et al. 2008).

\section{Effects of IGF1 in bovine superovulatory treatments}

\section{IGF1 concentrations during superovulation}

\section{Endocrine IGF1 production}

Most of the IGF1 detected in bovine antral follicles is derived from the peripheral circulation (Wathes et al. 2003, Sudo et al. 2007), but granulosa cells from superovulated cattle can produce IGF1 (Spicer et al. 1993). A positive correlation between IGF1 concentrations in blood and follicular fluid has been found in superovulated cattle (Herrler et al. 1994). Some investigations have observed that circulating IGF1 concentrations remained relatively constant during superovulatory treatments (Herrler et al. 1994, Cushman et al. 2001), suggesting that peripheral IGF1 levels of superovulated cows may be more related to nutritional intake rather than to the gonadotrophin treatment per se. However, other studies have indicated that both plasma (Kuehner et al. 1993) and follicular (O'Callagan et al. 2000) concentrations of IGF1 increase during superovulatory treatments. During a 5-day superovulatory treatment regime, increased concentrations of IGF1 in the plasma were observed in days 4 and 5 in comparison with days 1 and 2, and a positive correlation between IGF1 in the plasma and follicular fluid was found only on day 4 (Simpson et al. 1994). Increased follicular IGF1 concentrations were also found in gilts and goats treated with equine chorionic gonadotrophin (eCG) and $\mathrm{FSH}$ respectively, while the plasma levels were not altered (Khamsi et al. 2001a, Yu et al. 2003), indicating that intrafollicular IGF1 concentrations are affected more by the superovulatory treatment regime than peripheral concentrations. Whether this holds true for the oviducts and uterine horns of superovulated cows is unknown at present. In non-superovulated cattle, IGF1 concentrations in uterine luminal fluid and plasma were not correlated (Bilby et al. 2004, 2006). Therefore, circulating IGF1 might not always reflect the IGF1 milieu to which oocytes and embryos are exposed to during superovulation. Accordingly, IGF1 plasma concentrations cannot be used to predict the number of viable embryos in superovulated cattle, even though a positive correlation exists between these two variables (Velazquez et al. 2004). A similar situation has been reported in humans, where the serum concentrations of IGF1 did not allow the prediction of the ovarian response with regard to the numbers of oocytes retrieved after superovulation (Keay et al. 2003).

During superovulation, IGF1 changes in plasma are also mediated primarily through oestradiol (Kuehner et al. 1993). Oestradiol stimulates IGF1 secretion in the liver (Richards et al. 1991), via an increase in the number of $\mathrm{GH}$ receptors (Enright et al. 1994). Changes in IGF1 concentrations might depend on the magnitude of the increment in oestradiol, which in turn will depend on the superovulatory response, i.e. the number of gonadotrophin-active follicles responding to the superstimulatory treatment. Indeed, a higher number of corpora lutea was observed when peripheral IGF1 concentrations were affected by superovulation (Kuehner et al. 1993) compared with unchanged IGF1 concentrations (Herrler et al. 1994, Cushman et al. 2001).

\section{Paracrine IGF1 production}

Studies on IGF1 production in bovine oviducts and uterus during superovulation have not been reported. Analysis of gene expression and determination of concentrations in oviductal and uterine fluids would be critical for understanding embryo-hormonal milieu interactions. This information will be valuable for the development of improved culture conditions during in vitro embryo production, especially for humans undergoing superovulation during in vitro fertilizationembryo transfer (IVF-ET) cycles, where the same individual acts as donor and recipient.

\section{Effect of IGF1 during superovulation on follicular development and oocyte quality}

The variability within and between animals in both the number of follicles that are stimulated and the number that ovulate is the limiting factor for the success of ET programmes (Adams 1994, Kanitz et al. 2002, Mapletoft et al. 2002, 2006). The number of gonadotrophinresponsive follicles present in both ovaries at the start of a superovulatory treatment is important to achieve a satisfactory superstimulatory response (González-Bulnes et al. 2003). In superstimulated animals the preovulatory LH surge occurs earlier, which is associated with a lack of time for the follicles to acquire adequate maturation and thus to ovulate (D'Occhio et al. 1999). This indicates that oocytes with a proper maturational period during superovulation could yield more viable embryos. IGF1 accelerates the meiotic progress of bovine oocytes in small ( $\leq 3 \mathrm{~mm}$ ) follicles (Sakaguchi et al. 2000, 2002) and more viable embryos can be obtained in sheep (Veiga-Lopez et al. 2005) and cattle (Ireland et al. 2007) when a greater population of follicles around $3 \mathrm{~mm}$ in size is present at the time of stimulation. Accordingly, increments in blood IGF1 concentrations induced by bST treatment have been associated with increased numbers of follicles between 2 and $5 \mathrm{~mm}$ in diameter 
(Gong et al. 1991, 1993a, 1997, De la Sota et al. 1993). This treatment was also effective in increasing the superovulatory response in cattle (Gong et al. 1993b, 1996, Herrler et al. 1994). Statistically significant increases in ovulation rate in terms of numbers of corpora lutea and embryo viability due to bST treatment have been found in some, but not all studies (Table 3). Variability between experiments could be related to several factors including the dose of bST, method of ovarian examination, type and dose of gonadotrophin, and both number and body condition of animals used in such studies. The effect of bST has been suggested to be mediated through $\mathrm{GH}$, IGF1 and insulin acting either separately or in synergy (Gong et al. 1993b).

The effect of exogenous IGF1 on ovulation rate in cattle undergoing superovulatory treatments has not yet been tested. Studies in rats found that superovulated animals treated subcutaneously with Long R3 IGF1, which has negligible affinity for IGFBPs, had more ovulations than control animals (Khamsi et al. 2001 b). In peripubertal cattle, intraovarian injections of IGF1 $(6 \mu \mathrm{g})$ improved oocyte developmental competence in vitro in such a way that oocytes from superstimulated calves yielded a blastocyst rate similar to adult cattle (Oropeza et al. 2004). Oocytes from prepubertal calves showed a deficient mRNA expression pattern of facilitative glucose transporters and insufficient protein translation as compared to their adult counterparts (Oropeza et al. 2004). Hence, intraovarian IGF1 treatment may correct this 'deficient oocyte machinery' resulting in improved blastocyst formation. However, the developmental potential of blastocysts produced using this treatment needs to be analysed after transfer to recipients.

It has been hypothesized that elevated intraovarian IGF1 levels are associated with enhanced follicular growth, but that these could be detrimental to oocyte maturation in growing follicles (Armstrong et al. 2003). Indeed, higher levels of follicular IGF1 in superovulated ruminants have been associated with abnormal oocyte morphology (O'Callaghan et al. 2000). Likewise, in vitro treatment with high IGF1 concentrations did increase follicular size (Walters et al. 2006), but higher IGF1 exposure induced smaller oocytes in treated follicles (McCaffery et al. 2000). Development to the morula and blastocyst stages is positively associated with oocyte diameter (Arlotto et al. 1996). Failure of the oocyte to reach a proper size coincides with the inability to undergo meiotic maturation and increased frequency of polyspermic fertilization (Fair et al. 1995, Otoi et al. 1997). The potentially deleterious action of high IGF1 levels on oocyte competence has been demonstrated in women, where low concentrations of IGF1 in the

Table 3 Effect of bovine somatotrophin (bST) on the superovulatory response in cattle.

\begin{tabular}{|c|c|c|c|c|c|c|c|c|}
\hline \multirow[b]{2}{*}{ Type of animal ${ }^{a}$} & \multirow[b]{2}{*}{$\begin{array}{l}\text { Period of } \\
\text { treatment }^{\mathrm{b}}\end{array}$} & \multirow{2}{*}{$\begin{array}{l}\text { Amount } \\
\text { of bST } \\
(\mathrm{mg})\end{array}$} & \multirow[b]{2}{*}{ ORE } & \multicolumn{4}{|c|}{ Effect of treatment* } & \multirow[b]{2}{*}{ References } \\
\hline & & & & $\begin{array}{l}\text { Number } \\
\text { of } C L\end{array}$ & $\begin{array}{l}\text { Number } \\
\text { of } \mathrm{O} / \mathrm{E}\end{array}$ & $\begin{array}{l}\text { Number } \\
\text { of VP }\end{array}$ & $\begin{array}{l}\text { Percentage } \\
\text { of TE }\end{array}$ & \\
\hline Dairy heifers $(n=31)$ & During SOV (4 days) & 160 & PPR & $\uparrow$ & $\uparrow$ & $\uparrow$ & $\downarrow$ & Rieger et al. (1991) \\
\hline Beef $\times$ dairy heifers $(n=24)$ & Day 7, before SOV & 320 & LAP & $\uparrow$ & $\uparrow$ & $\uparrow$ & $\downarrow$ & Gong et al. (1993b) \\
\hline Beef $\times$ dairy heifers $(n=24)$ & Day 7 , before SOV & 320 & LAP & $\uparrow$ & $\uparrow$ & $\uparrow / \uparrow^{c}$ & $\downarrow$ & Gong et al. $(1993 b)$ \\
\hline Lactating beef cows $(n=10)$ & For 41 days before SOV & 25 & $?$ & $?$ & $\uparrow$ & $\uparrow$ & ? & Gray et al. (1993) \\
\hline Non-lactating beef cows $(n=10)$ & For 37 days before SOV & 25 & ? & ? & $\uparrow$ & $\uparrow$ & ? & Gray et al. (1993) \\
\hline Dairy heifers $(n=17)$ & Day 4, before SOV & 500 & ULT & $\uparrow$ & $\uparrow$ & $\uparrow$ & $\uparrow$ & Kuehner et al. (1993) \\
\hline Dairy heifers $(n=18)$ & Day 11 , first day of SOV & 500 & ULT & $\uparrow$ & $\uparrow$ & $\uparrow$ & $\uparrow$ & Kuehner et al. (1993) \\
\hline Dairy heifers $(n=17)$ & Day 15, after SOV & 500 & ULT & $\uparrow$ & $\uparrow$ & $\uparrow$ & $\uparrow$ & Kuehner et al. (1993) \\
\hline Dairy cows $(n=22)$ & Day 4, before SOV & 640 & SLA & $\uparrow$ & ? & $?$ & $?$ & Herrler et al. (1994) \\
\hline Dairy cows $(n=38)$ & Day 4, before SOV & 640 & SLA & $\uparrow$ & $\uparrow$ & $\uparrow$ & $\uparrow$ & Herrler et al. (1994) \\
\hline Dairy cows $(n=21)$ & Day 13, after SOV & 640 & SLA & $\uparrow$ & $\uparrow$ & $\uparrow$ & $?$ & Herrler et al. (1994) \\
\hline Beef $\times$ dairy heifers $(n=16)$ & Day 7 , before SOV & 320 & LAP & $\uparrow$ & $\uparrow$ & $\uparrow$ & $\uparrow$ & Gong et al. (1996) \\
\hline Beef $\times$ dairy heifers $(n=16)$ & Day 7, before SOV & 320 & LAP & $\uparrow$ & $\uparrow$ & $\uparrow$ & $\uparrow$ & Gong et al. (1996) \\
\hline Beef $\times$ dairy heifers $(n=12)$ & Day 7, before SOV & 320 & $?$ & $?$ & $\uparrow$ & $\uparrow$ & $\uparrow$ & Gong et al. (1996) \\
\hline Dairy cows $(n=27)$ & $\begin{array}{l}4 \text { to } 5 \text { doses, every } \\
14 \text { days, before SOV }\end{array}$ & 500 & SLA & $\uparrow / \uparrow^{d}$ & ? & ? & ? & Cushman et al. (2001) \\
\hline Beef cattle $(n=35)$ & $\begin{array}{l}5 \text { to } 6 \text { doses, every } \\
14 \text { days, before SOV }\end{array}$ & 500 & ? & $\uparrow$ & $\uparrow$ & $\uparrow$ & $?$ & Cushman et al. (2001) \\
\hline Dairy cows $(n=12)$ & At the time of first $\mathrm{Al}$ & 500 & ? & $?$ & $\uparrow$ & $\uparrow$ & $\uparrow$ & Moreira et al. (2002b) \\
\hline Beef cows $(n=57)$ & $\begin{array}{l}\text { One dose every } \\
14 \text { days for up to } 4 \\
\text { SOV }^{\text {e }}\end{array}$ & 500 & ? & $\uparrow$ & ? & $\uparrow$ & $?$ & Hasler et al. (2003) \\
\hline Beef cows $(n=37)$ & $\begin{array}{l}\text { One dose every } \\
14 \text { days for } 1 \mathrm{SOV}^{\mathrm{e}}\end{array}$ & 500 & ? & $\uparrow$ & ? & $\uparrow$ & ? & Hasler et al. (2003) \\
\hline
\end{tabular}

*Statistically significant $(P \leq 0.05)$; ORE, ovulation rate examination; $\mathrm{CL}$, corpora lutea; $\mathrm{O} / \mathrm{E}$, ova + embryos; VE, viable embryos; $\mathrm{TE}$, transferable embryos; SOV, superovulation; PPR, palpation per rectum; LAP, laparoscopy; ULT, ultrasonography; SLA, slaughter; ?, not reported; $\uparrow$, increase; $\downarrow$, decrease; $\uparrow$, no difference.

${ }^{a}$ Total number of animals in each experiment or study. ${ }^{b}$ Day 0 , day of oestrus. ${ }^{c}$ Depending on the dose of gonadotrophin. ${ }^{d}$ Depending on treatment

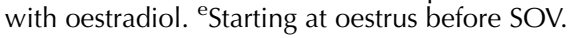


follicular fluid of patients undergoing superovulation were correlated with successful early embryo development (Wang et al. 2006). Albeit speculative, this inverse relationship between oocyte competence and high intrafollicular IGF1 concentrations might be related to the fact that when more ovulations occur during superovulation less viable embryos are produced (Driancourt 2001, Ireland et al. 2007). In this regard, it is worthy to mention that higher levels of intrafollicular IGF1 were observed after the use of FSH when compared with human menopausal gonadotrophin (hMG; Fried et al. 1998, Hammadeh et al. 2000), indicating that the intrafollicular concentrations of IGF1 can be affected by the type of hormone used for superstimulation. Bovine superovulation has been induced with $\mathrm{FSH}$ extracted from either porcine, ovine or equine pituitaries (Staigmiller et al. 1992, Kanuya et al. 1997), eCG (Gonzalez et al. 1994), hMG (Lauria et al. 1982), recombinant bovine FSH (Wilson et al. 1993) or recombinant human FSH (Takagi et al. 2001). Notwithstanding, the effect of different gonadotrophin preparations upon intrafollicular IGF1 concentrations has not yet been studied in cattle.

The other ligand of the IGF system, IGF2, is also increased in the follicular fluid by superovulation, and has been associated with decreased oocyte quality (O'Callaghan et al. 2000). In superstimulated women, high follicular concentrations of IGF2 were positively related to oocyte maturation and early embryo development (Wang et al. 2006). By contrast, the intrafollicular microenvironment of IGF2 was not associated with clinical outcome in the patients subjected to IVF-ET cycles (Choi et al. 2006). However, studies on the role of IGF2 during bovine superovulation are lacking.

Oocyte maturation has been positively associated with follicular fluid levels of IGF1 in women undergoing ovarian superstimulation (Nardo et al. 2001). IGF1 levels in follicular fluid compatible with bovine oocyte competence are modulated to a great extent by IGFBPs (Nicholas et al. 2005). It has been observed that the amount of IGFBP2, 4 and 5 in the follicular fluid of follicles $>8 \mathrm{~mm}$ from cows superstimulated with eCG was less compared with that of medium-sized follicles, and that IGFBP3 was present in all follicles (van de Leemput et al. 1997). FSH-stimulated cows had less IGFBP2 and relatively constant levels of IGFBP3 in large oestrogen-active follicles $(\sim 17 \mathrm{~mm}$ or greater $)$ compared with large oestrogen-inactive $(\sim 12-14 \mathrm{~mm})$, medium $(5-7 \mathrm{~mm}$ ) and small follicles ( $\leq 4 \mathrm{~mm}$; Echternkamp et al. 1994). Superovulated ewes had lower concentrations of IGFBP2, 4 and 5 than non-superovulated controls in follicular fluid from follicles $\geq 3 \mathrm{~mm}$ (O'Callaghan et al. 2000). In a model of follicular co-dominance induction, treatment with 2-6 mg recombinant bovine FSH for 36-48 $\mathrm{h}$ decreased the amounts of IGFBP2, 4 and 5, and increased levels of IGFBP3 and IGFBP proteases 4 and 5 in the follicular fluid of co-dominant follicles $(\sim 9-12 \mathrm{~mm})$ compared with subordinate follicles ( 7-9 mm; Rivera \& Fortune 2001, 2003). Although these findings partially suggest that the action of the IGFBP system during superovulation operates in a manner similar to non-superovulated conditions, more work is required to further elucidate the role of IGFBPs in follicular development during bovine superovulatory treatments.

\section{Effects of IGF1 during superovulation on preimplantation embryo development}

The main objective of a superstimulatory treatment is to obtain the maximum number of viable embryos with a high probability of producing pregnancies. Although the best indicator of the success of an ET programme is the number of live calves born per donor over a given period of time (Armstrong 1993), the number of viable embryos produced per donor is frequently used as an indicator of MOET success (Peixoto et al. 2002). Embryo viability in the MOET programmes is not only affected by the ovulation rate but also depends critically on whether normal fertilization occurs (Armstrong 1993) and the oviductal and uterine milieu in which the embryo develops prior to embryo recovery (Barnes 2000).

The IGF1 receptor mediates the effects of IGF1 during the preimplantation period (Matsui et al. 1997). Day 7 bovine embryos collected from superovulated animals express the IGF1 receptor (Bertolini et al. 2002, Moore et al. 2007). Receptors for IGF1 are also observed in embryos produced either partially (Lazzari et al. 2002, Lonergan et al. 2003) or totally by standard in vitro procedures (Watson et al. 1992, Yoshida et al. 1998, Yaseen et al. 2001, Lazzari et al. 2002, Moore et al. 2007) or by somatic cell nuclear transfer (Sawai et al. 2005, 2007, Moore et al. 2007). In vitro procedures can alter the relative abundance of IGF1 receptor transcripts in bovine embryos (Bertolini et al. 2002, Lazzari et al. 2002, Sawai et al. 2005, 2007, Warzych et al. 2007). Preimplantation embryos collected from superovulated cows have shown either high (Bertolini et al. 2002), low (Lazzari et al. 2002, Sawai et al. 2007) or similar (Moore et al. 2007) transcript abundance when compared with in vitro-produced embryos. It is unknown whether or not differences exist between embryos derived from single spontaneous ovulations and stimulated multiple ovulations, with regard to the expression of the IGF1 receptor.

Convincing evidence has demonstrated that IGF1 can affect positively embryos from superovulated cattle. Improvements in embryo production have been achieved by treating superovulated donors with bST (Gong et al. 1993b, 1996, Herrler et al. 1994, Cushman et al. 2001, Moreira et al. 2002b, Neves et al. 2005), which was associated with increments in IGF1 concentrations in follicular fluid and peripheral plasma (Herrler et al. 1994, Cushman et al. 2001). Since bST also exerts direct effects on several reproductive events, including 
embryogenesis (Kaiser et al. 2001, Sirotkin 2005), a complementary effect of bST and IGF1 cannot be ruled out. Support for a beneficial action of IGF1 on embryonic development during superovulation can be derived from the positive correlation found between the plasma concentrations of IGFI and the number of viable embryos produced by superovulated mature cows (Velazquez et al. 2005). Insulin is closely linked with IGF1 during superovulation as shown by the greater diameter of large follicles and increased levels of IGF1 in the follicular fluid induced with exogenous application of insulin during the period of gonadotrophin treatment (Simpson et al. 1994). Both hormones were found to be closely related with body condition score (BCS) and embryo production in superovulated cows (Velazquez et al. 2005; Table 4).

Diet-induced increases in circulating insulin were associated with the recruitment of small ovarian follicles that resulted in an enhanced superovulatory response in terms of both the number of preovulatory follicles and ovulations (Gong et al. 2002). However, it remains to be determined whether such an approach will also improve oocyte competence in vivo. Ovum pick-up/IVF models found that increased dietary intake over maintenance requirements in superovulated donors increased circulating concentrations of insulin and IGF1. However, this treatment started to have a negative impact on in vitro embryo production after 6 weeks of overfeeding (Freret et al. 2006). Reduced blastocyst yields were reported in cattle with moderately high BCS fed twice maintenance requirements. The increased dietary intake in heifers with moderately high BCS resulted in hyperinsulinaemia (Adamiak et al. 2005), similar to the values reported in women with the polycystic ovary syndrome (PCOS; Dunaif 1997). By contrast, higher dietary intake positively affected blastocyst production in animals with low BCS (Adamiak et al. 2005). The inverse relationship between overfeeding and embryo production has also been observed during in vivo embryo production (Yaakub et al. 1999, Siddiqui et al. 2002, Stroud \& Hasler 2006, Garcia Guerra et al. 2007, Kadokawa et al. 2008). These findings are in agreement with the hypothesis that a 'quiet' metabolism during early mammalian embryo development is positively associated with embryo viability (Leese 2002, 2003, Bauman et al. 2007, Leese et al. 2007). Although plasma IGF1 was not associated with impaired oocyte competence during over-nutrition (Adamiak et al. 2005), it cannot be completely ruled out, as a direct effect of liverproduced IGF1 on ovarian activity will depend on how much circulating bioactive IGF1 impacts on the ovaries. IGF1 in follicular fluid has been found to be either lower (Echternkamp et al. 1990, Spicer et al. 1991), equal (Spicer et al. 1992) or greater than peripheral IGF1 (Spicer et al. 1992, Ortega et al. 2008). This emphasizes the importance of measuring both IGF1 and IGFBPs concentrations in reproductive tracts in experimental trials.

Experiments in rodents found that locally enhanced IGF1 production in the uterus during a superovulatory treatment can be detrimental to early embryo development. This increase in IGF1 production is thought to be due to the hyperoestrogenaemia caused by superovulation, as uterine IGF1 production is primarily regulated by oestrogens (Murphy et al. 1987, Simmen et al. 1990, Sahlin et al. 1994, van Lier et al. 2006, Suzuki et al. 2007). Katagiri et al. (1996) reported a decrease in both the rate of blastocyst formation and blastocyst cell number, and an increased proportion of degenerated blastocysts after culturing eight-cell embryos with uterine luminal fluids isolated from rat uteri infused with IGF1, thus mimicking IGF1 concentrations caused during superovulation. The same results were obtained with uterine luminal fluid from superovulated animals, and even more interesting, a reversed trend was observed in both models (superovulation and IGF1 infusion) when the uterine fluids were treated with anti-IGF1 antibody (Katagiri et al. 1996). The same rat model was applied in a study in which an altered uterine electrolyte environment, especially cations, was suggested to be partially responsible for the detrimental effects of IGF1 on embryonic development after superovulatory treatment (Katagiri et al. 1997a). Recent studies have reported that exposure of mice embryos at the two- or four-cell stage to high IGF1 concentrations $(950 \mathrm{ng} / \mathrm{ml})$ triggered apoptosis in blastocysts via

Table 4 In vivo embryo production and insulin and insulin-like growth factor1 (IGF1) concentrations (mean \pm s.E.M.) in superovulated dairy cows associated with body condition score (BCS).

\begin{tabular}{lccc}
\hline & \multicolumn{3}{c}{ BCS (5 points scale) } \\
\cline { 2 - 4 } & $<2.5$ & $>2.5$ & $\boldsymbol{P}_{\text {value }}$ \\
\hline Ova +embryos $(n)$ & $7.0 \pm 1.4$ & $14.1 \pm 2.3$ & 0.042 \\
Viable embryos $(n)$ & $3.7 \pm 1.1$ & $8.9 \pm 1.8$ & 0.047 \\
Quality 1 embryos $(n)$ & $2.2 \pm 1.0$ & $5.8 \pm 1.5$ & $0.062^{\mathrm{b}}$ \\
Insulin $(\mu \mathrm{IU} / \mathrm{ml})$ & $10.0 \pm 2.4$ & $20.3 \pm 4.2$ & 0.031 \\
IGF1 $(\mathrm{ng} / \mathrm{ml})$ & $128.6 \pm 16.8$ & $207.5 \pm 28.0$ & 0.035 \\
\hline
\end{tabular}

$n$, total number. Based on data from Velazquez et al. (2005).

a Mann-Whitney test. ${ }^{b}$ Considered as a value towards significance. 
downregulation of the IGF1 receptor (Chi et al. 2000), which in turn increased embryo resorption rates (Pinto et al. 2002, Eng et al. 2007). It has been suggested that this high IGF1 induced apoptosis in embryos associated with reduced IGF1 receptor signalling requires activation of the TP53 pathway (Moley et al. 2005). However, extrapolation of the results from rodents to cattle needs to be done with caution. The downregulation of the IGF1 receptor found in bovine embryos treated with IGF1 concentrations considered beneficial for embryogenesis $(100 \mathrm{ng} / \mathrm{ml}$; Prelle et al. 2001) highlights the importance of species-specific differences on the detrimental effects of IGF1 upon embryonic development.

Partial evidence for an adverse effect of IGF1 in vivo was found in superovulated maiden heifers in which a negative correlation between embryonic viability and plasma concentrations of IGF1 was observed (Velazquez et al. 2005). The concentrations of IGF1 in blood are higher in heifers than in cows (Wathes et al. 2001, Velazquez et al. 2004). Therefore, both high endogenous concentrations and the superovulatory gonadotrophins might elevate IGF1 concentrations in both oviduct and uterus to a level that is suboptimal for embryonic development (Figs 1 and 2). The potential deleterious effects of high concentrations of IGF1 on embryo viability are also partially supported by studies in non-superovulated cows in which a decrease in pregnancy rates was attributed to the hyperstimulation of IGF1 production induced by bST treatment (Bilby et al. 2004).

\section{Modulation of the IGF system to improve results of superovulation in cattle}

IGF1 is able to cross the blood-brain barrier (Reinhardt \& Bondy 1994) and may act in either the hypothalamus and/or pituitary gland to modulate gonadotrophin secretion (Monget \& Martin 1997). Studies in rodents have found that IGF1 is produced in several regions of the nervous system, including the arcuate nucleus and median eminence of the brain, where $\mathrm{GnRH}$ regulates the ovarian production of gonadotrophins (Daftary \& Gore 2005). Accordingly, bovine IGF1 has been found to be involved in the regulation of $\mathrm{LH}$ release (Hashizume et al. 2002). No information is available regarding brain production of IGF1 in superovulated cattle. This may be especially relevant since it is known that nuclear and cytoplasmic maturation of bovine oocytes is critically dependent on precise patterns of LH secretion (Lindsey et al. 2002). Alteration in LH production associated with impaired oocyte maturation is one of the main problems caused by superovulation (D'Occhio et al. 1999).

The use of exogenous IGF1 to enhance in vivo embryo production in superovulated cows has not yet been tested. This approach could be useful to improve embryo yields in animals with reduced superovulatory response. Reliable methods for the prediction of embryo production in donor animals would be helpful in improving the outcome in the MOET programmes. Total plasma IGF1 concentrations have been found to be of limited value for the prediction of the number of viable embryos (Velazquez et al. 2005). Measuring the concentrations of

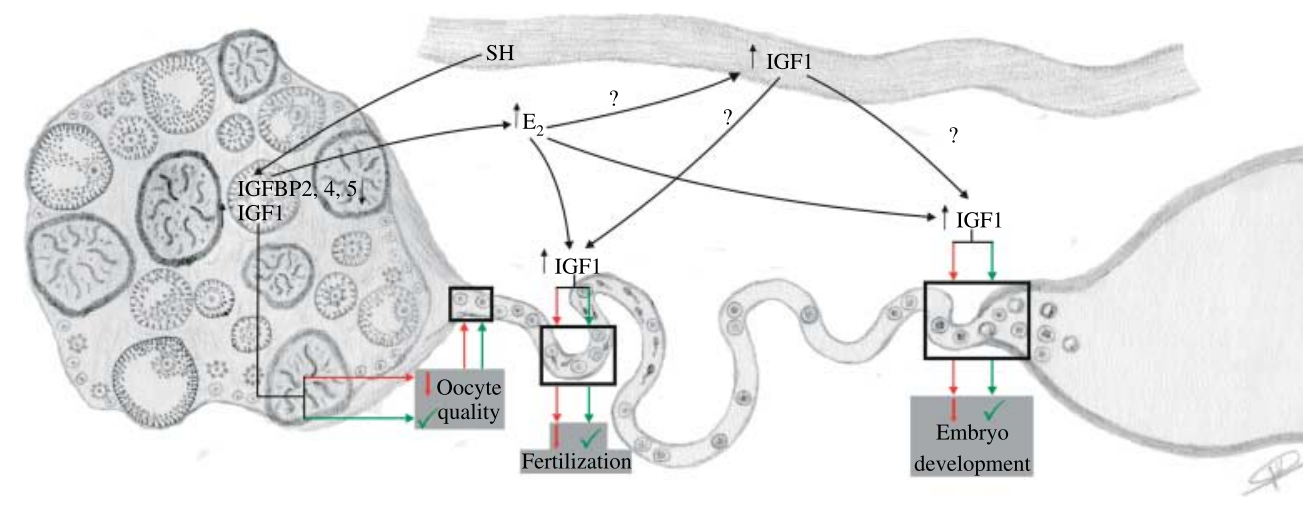

Figure 1 Possible effects of IGF1 on oocyte and preimplantation embryo development during superovulation in cattle. IGF1 milieu during gonadotrophic stimulation in follicles, oviduct and uterus will depend primarily on the dose and type of superstimulatory hormone (SH) used, the number of FSH-responding follicles at the time of treatment and the endocrine and paracrine production of IGF1 in the individual (inherent and nutritional induced). The stimulatory treatment will induce high oestradiol $\left(\mathrm{E}_{2}\right)$ production, which in turn will increase IGF1 production in reproductive tissues (paracrine) and possibly peripheral plasma (endocrine effect). The IGF1 increase in plasma could contribute even more to the paracrine effect of IGF1 during superovulation. This hyperstimulation of IGF1 is associated with the enhanced follicle growth occurring during superovulation. In the follicles destined to reach preovulatory size, the amount of IGFBP2, 4 and 5 will be decreased, allowing the increment of intrafollicular IGF1 concentrations. Positive effects on oocyte competence and embryo development are exerted by IGF1 when the concentrations remain within the normal physiological range (green arrows). If the superstimulatory response is too high, IGF1 concentrations are increased to supraphysiological levels, which could result in the ovulation of low-quality oocytes. The decrease in oocyte quality and the altered IGF1 environment present in the oviduct and uterus could interfere with the fertilization process and/or preimplantation embryo development (red arrows). 
circulating IGF1 and IGFBPs in combination could improve the prediction of the number of viable embryos. This is supported by the fact that mouse embryos cultured in medium supplemented with dephosphorylated IGFBP1 in the form of an IGF1/IGFBP1 complex showed a higher increase in the rate of blastocyst formation compared with supplementation with IGF1 alone (Lin et al. 2003). The ratio of IGF1 and IGFBP1 in serum and follicular fluid has been suggested to reflect oocyte quality, which in turn influences embryo viability (Fried et al. 2003).

Stimulatory gonadotrophin treatments can also affect gamete transport in the oviductal-uterine tract and the fertilization process (Greve \& Callesen 2001). IGF1 has been found in bovine seminal plasma and its receptor was present in ejaculated bovine sperm, indicating that it might play an important role during fertilization (Henricks et al. 1998, Hoeflich et al. 1999). In vitro studies have shown that treatment with IGF1 increased important characteristics of bovine spermatozoa, including the percentage of motile sperm and straight-line velocity (Henricks et al. 1998, Lackey et al. 1998). Significant fluctuations in the oviductal IGF1 concentrations have been found in superovulated ruminants (Kakar et al. 2005). However, the effects of different IGF1

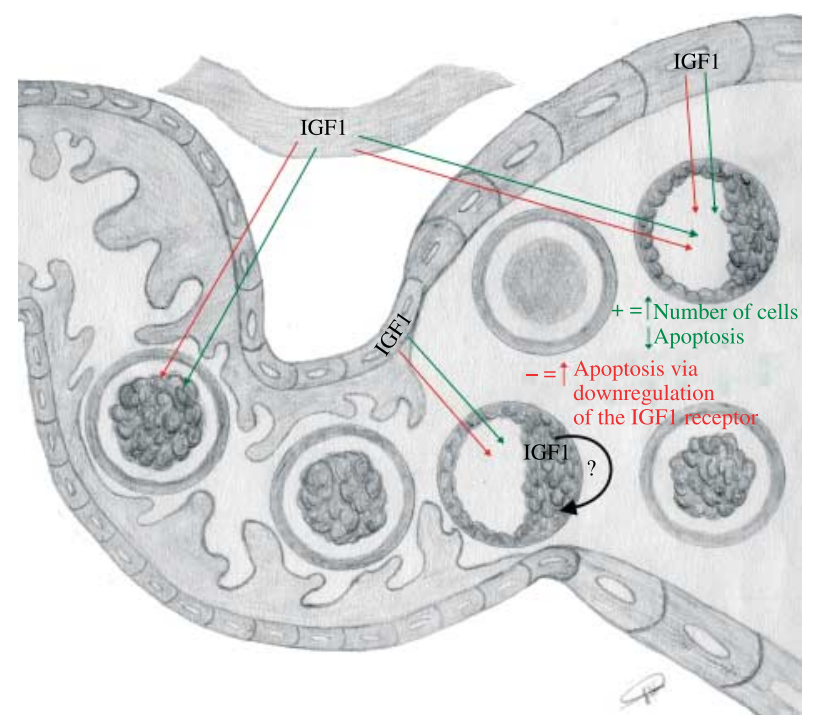

Figure 2 The oviductal-uterus milieu can exert negative and positive effects on preimplantation embryos during superovulation. The embryos will be affected mainly by the endocrine and/or paracrine production of IGF1 as autocrine production has still to be elucidated. When IGF1 production within the normal physiological range is maintained in the oviducts and uterus, it is suggested that there will be an increase in the number of cells and a decrease in the level of apoptosis in the preimplantation embryo $(+$, positive effect, green arrows). However, when this positive threshold is altered (higher IGF1 concentrations) due mainly to an over-response during gonadotrophin stimulatory treatment, the level of apoptosis increases. This negative effect would be associated with the downregulation of the IGF1 receptor (-, negative effect, red arrows). concentrations in oviducts during superovulatory treatments on sperm viability and fertilization success have not yet been studied.

Although IGF1 ligand expression in the preimplantation stage has been proposed as a potential marker for embryo quality in humans and mice (Liu et al. 1997, Kowalik et al. 1999), the autocrine role of IGF1 in bovine embryogenesis has not been fully elucidated. Some studies have reported expression of the IGF1 ligand in bovine embryos during the preimplantation period (Schultz et al. 1992, Yoshida et al. 1998, Lonergan et al. 2000), while others did not find the molecule (Yaseen et al. 2001, Bertolini et al. 2002, Moore et al. 2007, Warzych et al. 2007). Nevertheless, it would be useful to determine whether oestradiol concentrations, associated with the superovulatory response, do induce expression of the IGF1 ligand in embryos, as has been observed in some types of brain cells (Shingo \& Kito 2003).

It has been speculated that the high rates of embryonic mortality observed in dairy cows with severe negative energy balance could be due to impaired embryo development caused by increased signalling of IGF2 in the oviduct (Fenwick et al. 2008). Since IGF2 is produced in oviducts and uterus and both the ligand and the receptor are expressed from the zygote to the blastocyst stage (Yaseen et al. 2001), the interaction between IGF2 and preimplantation embryo development in superovulated cattle warrant future research.

\section{The superovulated bovine female as an alternative model to investigate reproductive endocrinological disorders associated with IGF1 in humans}

Female cattle and women share significant similarities regarding the final stages of oocyte maturation and the biochemical and intrinsic paternal and maternal regulatory processes in preimplantation embryos (Ménézo \& Hérubel 2002). Thus, domestic cattle could be a suitable experimental model to study the mechanisms controlling folliculogenesis (Campbell et al. 2003) and preimplantation embryo development in humans (Niemann \& Wrenzycki 2000, Wrenzycki et al. 2005, 2007, Bauman et al. 2007, Velazquez 2008). This approach could be extended to study reproductive endocrinological disorders associated with alterations of the IGF axis, such as the PCOS in humans. PCOS is a complex multifactorial disorder that accounts for more than $75 \%$ of the cases of anovulatory infertility (Gorry et al. 2006), and is responsible for up to $40 \%$ of human female sterility (Krysiak et al. 2006). The IGF system plays an important role in the pathogenesis of PCOS (Giudice 1992, Homburg et al. 1992, Druckman \& Rohr 2002). Patients with this disorder have significantly higher IGF1 concentrations in blood (Berker et al. 2004, Abd El Aal et al. 2005, Hahn et al. 2006) and ovarian 
follicular fluid (Eden et al. 1990) compared with women without PCOS. Recent data suggested that oocyte quality critically depends on the bioavailability of IGF1 in PCOS patients undergoing IVF-ET cycles (Schoyer et al. 2007).

As discussed above, high IGF1 concentrations associated with high superovulatory response may exert detrimental effects on oocyte and early embryo development in stimulated cattle. This raises the interesting possibility of producing high superovulatory profiles in domestic cattle, aiming at mimicking a polycystic-like ovarian milieu. This could be useful to develop strategies to enhance oocyte competence in order to improve the outcome of IVF-ET cycles in women with PCOS. Alternatively, this bovine model could be used to test the efficacy and/or to determine the method of action of drugs used for the treatment of PCOS, both in vivo and in vitro. Support for this hypothesis comes from in vitro studies recently carried out to investigate the effect of metformin on bovine ovarian steroidogenesis in response to IGF1 and FSH (Tosca et al. 2007). This drug is used for fertility treatment in women with PCOS (Palomba et al. 2008). Moreover, the use of artificial insemination in this bovine PCOS model could also be a valuable approach to study the fertilization success and preimplantation embryo development in vivo, with the goal of designing therapies to increase the chance of pregnancy in PCOS women.

Patients with PCOS that are stimulated in assisted reproduction cycles have an increased risk of developing the ovarian hyperstimulation syndrome (OHSS; Mikkelsen 2005, Tummon et al. 2005). Treatments leading to reduced IGF1 levels in blood of PCOS patients are associated with a decrease in ovarian stromal blood flow, which in turn is related to a lower likelihood of developing the OHSS (Amin et al. 2003). OHSS could also be investigated in the superovulated bovine model. For instance, after inducing a PCOS-like status by superovulation, animals developing multiple ovarian cysts (Todoroki et al. 2004) could be retreated with gonadotrophins in an attempt to mimic the conditions observed in humans. Another condition possibly associated with IGF1 is the low ovarian response after stimulation with gonadotrophins. Women with a poor response to ovarian stimulation have shown either similar (Hammadeh et al. 2003) or reduced levels of IGF1 in the follicular fluid (Bahceci et al. 2007) compared with good responders. Superovulated cattle could prove to be a superior approach to unravelling the underlying cause of this condition, as shown recently by Ireland et al. (2007). The feasibility of inducing these two contrasting superovulatory responses observed in women (OHSS and low ovarian response) is further supported by the fact that similar superovulatory profiles have been found in cattle, ranging from low to high responders (De Roover et al. 2005, Durocher et al. 2006).
Human polycystic ovaries have been shown to have a significantly reduced proportion of primordial follicles and an increased proportion of primary follicles compared with normal ovaries (Webber et al. 2003). It has been proposed that abnormal preantral folliculogenesis observed in polycystic ovaries is at least partially due to an excessive androgen exposure during the prenatal period (Forsdike et al. 2007). In primates, this androgen-induced ovarian follicular growth is thought to be mediated by an enhanced local IGF1 effect (Vendola et al. 1999). The accelerated progression of primordial follicles into the primary stages of development found in a prenatally androgenized sheep model is strikingly similar to the situation observed in women with PCOS (Forsdike et al. 2007). This model could be easily applied to cattle as both species have similar reproductive patterns (Campbell et al. 2003) and androgenization of cows is a well-established procedure in the cattle industry (Nix et al. 1998). Moreover, prenatally androgenized heifers used in a model to increase beef production showed higher body fat accumulation, higher serum IGF1 concentrations and a tendency for increased insulin levels compared with controls (Aldrich et al. 1995, 1996, Reiling et al. 1997). These features are largely similar to some characteristics of PCOS such as obesity and altered components of the IGF system (Chang 2007, Cocksedge 2008, Franks et al. 2008). Refinement of the bovine prenatal PCOS-like model will primarily relate androgen doses and timing of application during pregnancy. The assessment of the developmental competence of oocytes, both in vivo and in vitro, from adult superovulated cattle exposed to high androgens during foetal development may be relevant to the study of in utero programming of PCOS aetiology. The preantral stage last approximately 3 months in cattle (Webb \& Campbell 2007), and the environment to which preantral oocytes are exposed during this period could potentially affect future oocyte competence. This has been shown by Adamiak et al. (2005) in a nonsuperovulated cattle model, in which nutritionalinduced hyperinsulinaemia, similar to the high insulin concentrations present in PCOS, during three consecutive oestrous cycles induced a detrimental effect on oocyte developmental competence in vitro. It would be interesting to analyse the IGF system in the reproductive tract using this hyperinsulinaemic model, in conjunction with superovulation, to further explore embryomaternal interactions under PCOS-like conditions.

Creation of a 'universal' PCOS animal model is unlikely, as the induction of all pathological conditions observed in PCOS women is not possible (Szukiewicz \& Uilenbroek 1998, Singh 2005). Common clinical features of PCOS include polycystic ovaries, anovulation, hyperinsulinaemia, hyperandrogenism and hypersecretion of LH (Chang 2007, Cocksedge 2008, Franks et al. 2008). Still, the ultimate diagnostic criterion for PCOS is controversial and several phenotypes have been 
proposed. For instance, a patient with anovulation and polycystic ovaries but with no clinical or biochemical evidence of androgen excess can be diagnosed as having PCOS (Norman et al. 2007). Development of a suitable animal model critically depends on the PCOS-related disorder to be investigated (Szukiewicz \& Uilenbroek 1998). Although the model for prenatal exposure of androgens is hypothetical in cattle, some clinical conditions present in PCOS have been observed in cows, including polycystic ovaries, anovulation (Todoroki \& Kaneko 2006) and hyperinsulinaemia (Adamiak et al. 2005).

Since the increase in uterine IGF1 concentrations following superovulation is related to hyperoestrogenaemia (Katagiri et al. 1997b), and high uterine maternal levels of oestrogen and IGF1 are linked to endometrial cancer (Schernhammer 2002, Moyano \& Rotwein 2004), models to study uterine cancer development could also be created in superovulated cattle. This might be accomplished by the combined use of oestrogen implants and gonadotrophin stimulation, which could be applied as a chronic intermittent treatment monitored over the years. The suitability of this model, with regard to long-term monitoring and induction of neoplastic tumours, is supported partially by the current use of domestic cattle for the study of reproductive aging in women (Malhi et al. 2005, 2006) and the documentation of tumours in the bovine reproductive tract (García-Iglesias et al. 1991, 1995, Pérez-Martínez et al. 2001).

Cattle models are especially relevant as procedures that are rarely applied in women can be carried out more frequently in cattle, including intrafollicular drug treatments (Oropeza et al. 2004, 2006), interfollicular oocyte transfer (Bergfelt et al. 1998), intrafallopian transfer of gametes (Wetscher et al. 2005) and oviductal recovery and transfer of early embryos (Besenfelder \& Brem 1998, Besenfelder et al. 2001). Valuable data could also be obtained with this experimental approach, especially when using in vivo collection and monitoring techniques presently used in women and already validated in cattle, such as cytology (Kasimanickam et al. 2004) and biopsy (Katagiri \& Takahashi 2004) of endometrial tissue and reproductive ultrasound techniques (Rajamahendran et al. 1994, Ribadu \& Nakao 1999, Miyamoto et al. 2006, Oropeza et al. 2006). Moreover, several variables such as nutrition, age, health and parity can be precisely controlled in cattle populations.

\section{Conclusions}

IGF1 is only one member of the complex IGF family. The important role of IGF1 in follicular development, oocyte quality and embryo development is well documented in non-superovulated cattle. Similarly, IGF1 has been found to be directly correlated with the production of viable embryos during superovulatory treatments.
The IGF1 milieu during superovulation in follicles, oviducts and uteri will depend on the inherent endocrine and paracrine secretion and on the nutritional- and gonadotrophin-induced production of IGF1. IGF2 acting via the IGF1 receptor could also affect the oocyte quality during superstimulatory protocols. There is an undetermined threshold in which IGF1 concentrations are detrimental for embryogenesis during superovulation. This negative effect is associated with high superovulatory responses that cause increments in oestrogen production and consequently increased IGF1 concentrations in the reproductive tract. These high IGF1 concentrations can affect embryo viability indirectly via oocyte quality during follicular development, and/or directly during the preimplantation period. Alterations in oocyte morphology and oocyte size are among the observed changes caused by high IGF1 concentrations in ruminants. Detrimental effects of high IGF1 levels on embryos have been suggested to be via induction of apoptosis, associated with a downregulation of the IGF1 receptor. The latter, however, still needs to be investigated in bovine embryos. There are still a number of unexplored aspects of the IGF system that needs to be elucidated to improve further responses following superovulatory treatments. As well as improvements in animal production, human-assisted reproduction could also benefit. Furthermore, superovulated cattle could serve as an excellent alternative animal model for investigating reproductive endocrinological disorders associated with variable IGF1 concentrations in women.

\section{Declaration of interest}

The authors declare that there is no conflict of interest that would prejudice the impartiality of this scientific work.

\section{Funding}

This research did not receive any specific grant from any funding agency in the public, commercial or not-for-profit sector.

\section{Acknowledgements}

M A Velazquez is in the PhD programme of the University of Veterinary Medicine, Hannover, Germany, and is supported by the German Academic Exchange Service (DAAD).

\section{References}

Abd El Aal DEM, Mohamed SA, Amine AF \& Meki A-RMA 2005 Vascular endothelial growth factor and insulin-like growth factor-1 in polycystic ovary syndrome and their relation to ovarian blood flow. European Journal of Obstetrics, Gynecology, and Reproductive Biology 118 219-224. 
Adamiak SJ, Mackie K, Watt RG, Webb R \& Sinclair KD 2005 Impact of nutrition on oocyte quality: cumulative effects of body composition and diet leading to hyperinsulinemia in cattle. Biology of Reproduction $\mathbf{7 3}$ 918-926.

Adams GP 1994 Control of ovarian follicular wave dynamics in cattle: implications for synchronization and superstimulation. Theriogenology 41 19-24.

Aldrich SL, Berger LL, Reiling BA, Kesler DJ \& Nash TG 1995 Parturition and periparturient reproductive and metabolic hormone concentrations in prenatally androgenized beef heifers. Journal of Animal Science $\mathbf{7 3}$ 3712-3718.

Aldrich SL, Berger LL, Kesler DJ, Nash TG \& McCusker RH Jr 1996 Effects of prenatal androgenization and postnatal steroid treatment on growth hormone, insulin-like growth factor I and II, insulin, thyroxine, and triidothyronine concentrations in beef heifers. Journal of Animal Science 74 420-428.

Amin AF, Abd El Aal D-EM, Darwish AM \& Meki A-RMA 2003 Evaluation of the impact of laparoscopic ovarian drilling on Doppler indices of ovarian stromal blood flow, serum vascular endothelial growth factor, and insulin-like growth factor-1 in women with polycystic ovary syndrome. Fertility and Sterility 79 938-941.

Arlotto T, Schwartz J-L, First NL \& Leidfried-Rutledge ML 1996 Aspects of follicle and oocyte stage that affect in vitro maturation and development of bovine oocytes. Theriogenology 45 943-956.

Armstrong DT 1993 Recent advances in superovulation of cattle. Theriogenology 39 7-24.

Armstrong DG, Gutierrez CG, Baxter G, Glazyrin AL, Mann GE, Woad KJ, Hogg CO \& Webb R 2000 Expression of mRNA encoding IGF-I, IGF-II and type 1 IGF receptor in bovine ovarian follicles. Journal of Endocrinology 165 101-113.

Armstrong DG, McEvoy TG, Baxter G, Robinson JJ, Hogg CO, Woad KJ, Webb R \& Sinclair KD 2001 Effect of energy and protein on bovine follicular dynamics and embryo production in vitro: associations with the ovarian insulin-like growth factor system. Biology of Reproduction $\mathbf{6 4}$ 1624-1632.

Armstrong DG, Gong JG \& Webb R 2003 Interactions between nutrition and ovarian activity in cattle: physiological, cellular and molecular mechanisms. Reproduction 61 403-414.

Austin EJ, Mihm M, Evans ACO, Knight PG, Ireland JLH, Ireland JJ \& Roche JF 2001 Alterations in intrafollicular regulatory factors and apoptosis during selection of follicles in the first follicular wave of the bovine estrous cycle. Biology of Reproduction 64 839-848.

Bahceci M, Ulug U, Turan E \& Akman MA 2007 Comparisons of follicular levels of sex steroids, gonadotropins and insulin-like growth factor-1 (IGF-1) and epidermal growth factor (EGF) in poor responder and normoresponder patients undergoing ovarian stimulation with $\mathrm{GnRH}$ antagonist. European Journal of Obstetrics, Gynecology, and Reproductive Biology 130 93-98.

Baker J, Hardy MP, Zhou J, Bondy C, Lupu F, Bellvé AR \& Efstratiadis A 1996 Effects of an Igf1 gene null mutation on mouse reproduction. Molecular Endocrinology 10 903-918.

Barnes FL 2000 The effects of early uterine environment on the subsequent development of embryo and fetus. Theriogenology 53 649-658.

Bauman CG, Morris DG, Sreenan JM \& Leese HJ 2007 The quiet embryo hypothesis: molecular characteristics favoring viability. Molecular Reproduction and Development 74 1345-1353.

Baxter RC 2000 Insulin-like growth factor (IGF)-binding proteins: interactions with IGFs and intrinsic bioactivities. American Journal of Physiology. Endocrinology and Metabolism 278 E967-E976.

Beg MA \& Ginther OG 2006 Follicle selection in cattle and horses: role of intrafollicular factors. Reproduction 132 365-377.

Bergfelt DR, Brogliatti GM \& Adams GP 1998 Gamete recovery and follicular transfer (GRAFT) using transvaginal ultrasonography in cattle. Theriogenology $\mathbf{5 0} 15-25$.

Berker B, Emral R, Demirel C, Corapcioglu D, Unlu C \& Kose K 2004 Increased insulin-like growth factor-1 levels in women with polycystic ovary syndrome, and beneficial effects of metformin therapy. Gynecological Endocrinology 19 125-133.

Bertolini M, Beam SW, Shim H, Bertolini LR, Moyer AL, Famula TR \& Anderson GB 2002 Growth, development, and gene expression by in vivo- and in vitro-produced day 7 and 16 bovine embryos. Molecular Reproduction and Development 63 318-328.
Besenfelder U \& Brem G 1998 Tubal transfer of bovine embryos: a simple endoscopic method reducing long-term exposure of in vitro produced embryos. Theriogenology $\mathbf{5 0}$ 739-745.

Besenfelder U, Havlicek V, Mösslacher G \& Brem G 2001 Collection of tubal stage embryos by means of endoscopy a technique report. Theriogenology 55 837-845.

Bilby TR, Guzeloglu A, Kamimura S, Pancarci SM, Michel F, Head HH \& Thatcher WW 2004 Pregnancy and bovine somatotropin in nonlactating dairy cows: 1 . Ovarian conceptus, and insulin-like growth factor system responses. Journal of Dairy Science 87 3256-3267.

Bilby TR, Sozzi A, Lopez MM, Silvestre FT, Ealy AD, Staples CR \& Thatcher WW 2006 Pregnancy, bovine somatotropin, and dietary n-3 fatty acids in lactating dairy cows: 1 . Ovarian, conceptus, and growth hormone-insulin-like growth factor system responses. Journal of Dairy Science 89 3360-3374.

Block J 2007 Use of insulin-like growth factor-1 to improve post-transfer survival of bovine embryos produced in vitro. Theriogenology 68 S49-S55.

Block J \& Hansen PJ 2007 Interaction between season and culture with insulin-like growth factor- 1 on survival of in vitro produced embryos following transfer to lactating cows. Theriogenology 67 1518-1529.

Block J, Drost M, Monson RL, Rutledge JJ, Rivera RM, Paula-Lopes FF, Ocon OM, Krininger CE III, Liu J \& Hansen PJ 2003 Use of insulin-like growth factor-I during embryo culture and treatment of recipients with gonadotropin-releasing hormone to increase pregnancy rates following the transfer of in vitro-produced embryos to heat-stressed, lactating cows. Journal of Animal Science 81 1590-1602.

Block J, Wrenzycki C, Niemann H, Herrmann D \& Hansen PJ 2008 Effects of insulin-like growth factor- 1 on cellular and molecular characteristics of bovine blastocyst produced in vitro. Molecular Reproduction and Development 75 895-903.

Butler AA \& Le Roith D 2001 Control of growth by the somatropic axis: growth hormone and the insulin-like growth factors have related and independent roles. Annual Review of Physiology 63 141-164.

Byrne AT, Southgate J, Brison DR \& Leese HJ 2002a Regulation of apoptosis in the bovine blastocyst by insulin and the insulin-like growth factor (IGF) superfamily. Molecular Reproduction and Development 62 489-495.

Byrne AT, Southgate J, Brison DR \& Leese HJ $2002 b$ Effects of insulin-like growth factors I and II on tumour-necrosis-factor- $\alpha$-induced apoptosis in early murine embryos. Reproduction, Fertility, and Development 14 79-83.

Campbell BK, Souza C, Gong J, Webb R, Kendall N, Masters P, Robinson G, Mitchell A, Telfer EE \& Baird DT 2003 Domestic ruminants as models for the elucidation of the mechanisms controlling ovarian follicle development in humans. Reproduction 61 429-443.

Canty MJ, Boland MP, Evans ACO \& Crowe MA 2006 Alterations in follicular IGFBP mRNA expression and follicular fluid IGFBP concentrations during the first follicle wave in beef heifers. Animal Reproduction Science 93 199-217.

Chang RJ 2007 The reproductive phenotype in polycystic ovary syndrome. Nature Clinical Practice. Endocrinology \& Metabolism 3 688-695.

Chi MM-Y, Schlein AL \& Moley KH 2000 High insulin-like growth factor 1 (IGF-1) and insulin concentrations trigger apoptosis in the mouse blastocyst via down-regulation of the IGF-1 receptor. Endocrinology 141 4784-4792.

Choi YS, Ku S-Y, Jee B-C, Suh C-S, Choi YM, Kim JG, Moon SY \& Kim SH 2006 Comparison of follicular fluid IGF-I, IGF-II, IGFBP-3, IGFBP-4 and PAPP-A concentrations and their ratios between GnRH agonist and GnRH antagonist protocols for controlled ovarian stimulation in IVFembryo transfer patients. Human Reproduction 21 2015-2021.

Clemmons DR 1998 Role of insulin-like growth factor binding proteins in controlling IGF actions. Molecular and Cellular Endocrinology 140 $19-24$.

Cocksedge K 2008 A reappraisal of the role of polycystic ovary syndrome in recurrent miscarriage. Reproductive Biomedicine Online 17 151-161.

Cohick WS, Armstrong JD, Whitacre MD, Lucy MC, Harvey RW \& Campbell RM 1996 Ovarian expression of insulin-like growth factor-I (IGF-I), IGF binding proteins, and growth hormone $(\mathrm{GH})$ receptor in heifers actively immunized against $\mathrm{GH}$-releasing factors. Endocrinology 137 1670-1677. 
Cushman RA, DeSouza JC, Hedgpeth VS \& Britt JH 2001 Effect of long-term treatment with recombinant bovine somatotropin and estradiol on hormone concentrations and ovulatory response of superovulated cattle. Theriogenology 55 1533-1547.

Daftary SS \& Gore AC 2005 IGF-1 in the brain as a regulator of reproductive neuroendocrine function. Experimental Biology and Medicine 230 292-306.

Daughaday WH, Hall K, Raben MS, Salmon WD Jr, Van Den Brande JL \& Van Wik JJ 1972 Somatomedin: proposed designation for sulphation factor. Nature 235107.

Díaz-Cueto L \& Gerton GL 2001 The influence of growth factors on the development of preimplantation mammalian embryos. Archives of Medical Research 32 619-626.

Diskin MG, Mackey DR, Roche JF \& Sreenan JM 2003 Effects of nutrition and metabolic status on circulating hormones and ovarian follicle development in cattle. Animal Reproduction Science 78 345-370.

D'Occhio MJ, Jillella D \& Lindsey BR 1999 Factors that influence follicle recruitment, growth and ovulation during ovarian superstimulation in heifers: opportunities to increase ovulation rate and embryo recovery by delaying the exposure of follicles to LH. Theriogenology 51 9-35.

Driancourt MA 2001 Regulation of ovarian follicular dynamics in farm animals. Implications for manipulation of reproduction. Theriogenology 55 1211-1239.

Druckman R \& Rohr UD 2002 IGF-1 in gynaecology and obstetrics: update 2002. Maturitas 41 S65-S83.

Dunaif A 1997 Insulin resistance and the polycystic ovary syndrome: mechanism and implications for pathogenesis. Endocrine Reviews $\mathbf{1 8}$ 774-800.

Durocher J, Morin N \& Blondin P 2006 Effect of hormonal stimulation on bovine follicular response and oocyte developmental competence in a commercial operation. Theriogenology 65 102-115.

Echternkamp SE, Spicer LJ, Gregory KE, Canning SF \& Hammond JM 1990 Concentrations of insulin-like growth factor-I in blood and ovarian follicular fluid of cattle selected for twins. Biology of Reproduction 43 8-14.

Echternkamp SE, Howard HJ, Roberts AJ, Grizzle J \& Wise T 1994 Relationships among concentrations of steroids, insulin-like growth factor-1, and insulin-like growth factor binding proteins in ovarian follicular fluid of beef cattle. Biology of Reproduction 51 971-981.

Echternkamp SE, Roberts AJ, Lunstra DD, Wise T \& Spicer LJ 2004 Ovarian follicular development in cattle selected for twin ovulations and births. Journal of Animal Science 82 459-471.

Eden JA, Jones J, Carter GD \& Alaghband-Zadeh J 1990 Follicular fluid concentrations of insulin-like growth factor 1 , epidermal growth factor, transforming growth factor-alpha and sex steroids in volume matched normal and polycystic human follicles. Clinical Endocrinology 32 395-405.

Eng GS, Sheridad RA, Wyman A, Chi MM, Bibee KP, Jungheim ES \& Moley KH 2007 AMP kinase activation increases glucose uptake, decreases apoptosis, and improves pregnancy outcome in embryos exposed to high IGF-I concentrations. Diabetes 56 2228-2234.

Enright WJ, Spicer LJ, Prendiville DJ, Murphy MG \& Campbell RM 1994 Interaction between dietary intake and ovariectomy on concentrations of insulin-like growth factor-I, GH and $\mathrm{LH}$ in plasma of heifers. Theriogenology 41 1231-1240.

Fabian D, II'ková G, Rehak P, Czikková S, Baran V \& Koppel J 2004 Inhibitory effect of IGF-I on induced apoptosis in mouse preimplantation embryos cultured in vitro. Theriogenology 61 745-755.

Fair T, Hyttel P \& Greve T 1995 Bovine oocyte diameter in relation to maturational competence and transcriptional activity. Molecular Reproduction and Development 42 437-442.

Fenwick MA, Llewellyn S, Fitzpatrick R, Kenny DA, Murphy JJ, Patton J \& Wathes DC 2008 Negative energy balance in dairy cows is associated with specific changes in IGF-binding protein expression in the oviduct. Reproduction 135 63-75.

Firth SM \& Baxter RC 2002 Cellular actions of the insulin-like growth factor binding proteins. Endocrine Reviews 23 824-854.

Flood MR, Gage TL \& Bunch TD 1993 Effect of various growth-promoting factors on preimplantation bovine embryo development in vitro. Theriogenology 39 823-833.
Forsdike RA, Hardy K, Bull L, Stark J, Webber LJ, Stubbs S, Robinson JE \& Franks SJ 2007 Disordered follicle development in ovaries of prenatally androgenized ewes. Journal of Endocrinology 192 421-428.

Fortune JE 2003 The early stages of follicular development: activation of primordial follicles and growth of preantral follicles. Animal Reproduction Science 78 135-163.

Francis GL, Ross M, Ballard JF, Milner SJ, Senn C, McNeil KA, Wallace JC, King R \& Wells JR 1992 Novel recombinant fusion protein analogues of insulin-like growth factor (IGF)-I indicate the relative importance of IGFbinding protein and receptor binding for enhanced biological potency. Journal of Molecular Endocrinology 8 213-223.

Franks S, Stark J \& Hardy K 2008 Follicle dynamics and anovulation in polycystic ovary syndrome. Human Reproduction Update 14 367-378.

Freret S, Grimard B, Ponter AA, Joly C, Ponsart C \& Humblot P 2006 Reduction of body-weight gain enhances in vitro embryo production in overfed superovulated dairy heifers. Reproduction 131 783-794.

Fried G, Wramsby H \& Tally M 1998 Transforming growth factor- $\beta 1$, insulin-like growth factors, and insulin-like growth factor binding proteins in ovarian follicular fluid are differentially regulated by the type of ovarian hyperstimulation used for in vitro fertilization. Fertility and Sterility 70 129-134.

Fried G, Remaeus K, Harlin J, Krog E, Csemiczky G, Aanesen A \& Tally M 2003 Inhibin B predicts oocyte number and the ratio IGF-I/IGFBP-1 may indicate oocyte quality during ovarian hyperstimulation for in vitro fertilization. Journal of Assisted Reproduction and Genetics 20 167-176.

Froesch ER, Bürgi H, Ramseier EB, Bally P \& Labhart A 1963 Antibodysuppressible and non-suppressible insulin-like activities in human serum and their physiologic significance. An insulin assay with adipose tissue of increased precision and specificity. Journal of Clinical Investigation $\mathbf{4 2}$ 1816-1834.

Funston RN, Seidel GE Jr, Klindt J \& Roberts AJ 1996 Insulin-like growth factor 1 and insulin-like growth factor binding proteins in bovine serum and follicular fluid before and after the preovulatory surge of luteinizing hormone. Biology of Reproduction 55 1390-1396.

Garcia Guerra A, Rodriguez D, Villareal J, Albrecht A \& Brogliatti G 2007 Effects of condition score on ovarian response and transferable embryos in superstimulated cows in Argentina. Reproduction, Fertility, and Development 19 307-308 (abstract).

Garcia Iglesias MJ, Martinez Rodriguez JM, Bravo Moral AM \& Escudero Diez A 1991 Common epithelial tumours of the ovary in cows. Research in Veterinary Science $\mathbf{5 0}$ 358-359.

Garcia-Iglesias MJ, Bravo-Moral AM, Perez-Martinez C, Ferreras-Estrada MC, Martinez-Rodriguez JM \& Escudero-Diez A 1995 Incidence and pathomorphology of uterine tumours in the cow. Zentralblatt Für Veterinärmedizin Reihe A 42 421-429.

Garnsworthy PC, Sinclair KD \& Webb R 2008 Integration of physiological mechanisms that influence fertility in dairy cows. Animal 2 1144-1152.

Geisert RD, Lee C-Y, Simmen FA, Zavy MT, Fliss AE, Bazer FW \& Simmen RCM 1991 Expression of messenger RNAs encoding insulin-like growth factor-I, -II, and insulin-like growth factor binding protein-2 in bovine endometrium during the estrous cycle and early pregnancy. Biology of Reproduction 45 975-983.

Giudice LC 1992 Insulin-like growth factors and ovarian follicular development. Endocrine Reviews 13 641-669.

Giudice LC 1995 The insulin-like growth factor system in normal and abnormal human ovarian follicle development. American Journal of Medicine 98 48S-54S.

Glabowski W, Kurzawa R, Wiszniewska B, Baczkowski T, Marchlewicz M \& Brelik P 2005 Growth factors effects on preimplantation development of mouse embryos exposed to tumor necrosis factor alpha. Reproductive Biology 5 83-99.

Glister C, Tanneta DS, Groome NP \& Knight PG 2001 Interactions between follicle-stimulating hormone and growth factors in modulating secretion of steroids and inhibin-related peptides by non-luteinized bovine granulosa cells. Biology of Reproduction 65 1020-1028.

Glister C, Groome NP \& Knight PG 2003 Oocyte-mediated suppression of follicle-stimulating hormone- and insulin-like growth factor-induced secretion of steroids and inhibin-related proteins by bovine granulose cells in vitro: possible role of transforming growth factor. Biology of Reproduction 68 758-765. 
Glister C, Groome NP \& Knight PG 2006 Bovine follicle development is associated with divergent changes in activin-A, inhibin-A and follistatin and the relative abundance of different follistatin isoforms in follicular fluid. Journal of Endocrinology 188 215-225.

Gong JG 2002 Influence of metabolic hormones and nutrition on ovarian follicle development in cattle: practical implications. Domestic Animal Endocrinology 23 229-241.

Gong JG, Bramley T \& Webb R 1991 The effect of recombinant bovine somatotropin on ovarian function in heifers: follicular populations and peripheral hormones. Biology of Reproduction 45 941-949.

Gong JG, Bramley TA \& Webb R 1993a The effect of recombinant bovine somatotrophin on ovarian follicular growth and development in heifers. Journal of Reproduction and Fertility 97 247-254.

Gong JG, Bramley TA, Wilmut I \& Webb R 1993b Effect of recombinant bovine somatotropin on the superovulatory response to pregnant mare serum gonadotropin in heifers. Biology of Reproduction 48 1141-1149.

Gong JG, Wilmut I, Bramley TA \& Webb R 1996 Pretreatment with recombinant bovine somatotropin enhances the superovulatory response to FSH in heifers. Theriogenology 45 611-622.

Gong JG, Baxter G, Bramley T \& Webb R 1997 Enhancement of ovarian follicle development in heifers by treatment with recombinant bovine somatotrophin: a dose-response study. Journal of Reproduction and Fertility 110 91-97

Gong JG, Armstrong DG, Baxter G, Hogg CO, Garnsworthy PC \& Webb R 2002 The effect of increased dietary intake on superovulatory response to FSH in heifers. Theriogenology 57 1591-1602.

Gonzalez A, Wang H, Carruthers TD, Murphy BD \& Mapletoft RJ 1994 Superovulation in the cow with pregnant mare serum gonadotrophin: effects of dose and antipregnant mare serum gonadotrophin serum. Canadian Veterinary Journal 35 158-162.

González-Bulnes A, García-García RM, Castellanos V, Santiago-Moreno J, Varreta CA, Domínguez V, López-Sebastián A, Tresguerres JAF \& Cocero MJ 2003 Influence of maternal environment on the number of transferable embryos obtained in response to superovulatory FSH treatments in ewes. Reproduction, Nutrition, Development 43 17-28.

Gorry A, White DM \& Frank S 2006 Infertility in polycystic ovary syndrome: focus on low-dose gonadotrophin treatment. Endocrine 30 27-33.

Gradela A, Roncoletta M, Morani ESC, Esper CR \& Franceschini PH 1998 Insulin-like growth factors-binding proteins and follicular dominance in Bos taurus indicus pure and crossed cows. Brazilian Journal of Veterinary Research and Animal Science 35 218-220.

Gray B, Stringfellow D, Riddell M, Riddell K, Davenport G \& Wright J 1993 The effect of treatment with bovine somatotropin (BST) on the superovulatory response of cattle. Theriogenology 39227 (abstract).

Greve T \& Callesen H 2001 Rendez-vouz in the oviduct: implications for superovulation and embryo transfer. Reproduction, Nutrition, Development 41 451-459.

Gutierrez CG, Ralph JH, Telfer EE, Wilmut I \& Webb R 2000 Growth and antrum formation of bovine preantral follicles in long-term culture in vitro. Biology of Reproduction 62 1322-1328.

Hahn S, Bering van Halteren W, Roesler S, Schmidt M, Kimmig R, Tan S, Mann K \& Janssen OE 2006 The combination of increased ovarian volume and follicle number is associated with more severe hyperandrogenism in German women with polycystic ovary syndrome. Experimental and Clinical Endocrinology and Diabetes 114 175-181.

Hammadeh ME, Braemert B, Baltes S, Georg T, Rosenbaum P \& Schmidt W 2000 Relationship between ovarian stimulation regime and cytokine concentration in follicular fluid and their effect on fertilization and pregnancy outcome of patients undergoing ICSI program. American Journal of Reproductive Immunology 43 12-20.

Hammadeh ME, Fischer-Hammadeh C, Georg T, Rosenbaum P \& Schmidt W 2003 Comparison between cytokine concentration in follicular fluid of poor and high responder patients and their influence of ICSI-outcome. American Journal of Reproductive Immunology $\mathbf{5 0}$ $131-136$

Hardy K \& Spanos S 2002 Growth factor expression and function in the human and mouse preimplantation embryo. Journal of Endocrinology 172 221-236.

Hashizume T, Kumahara A, Fujino M \& Okada K 2002 Insulin-like growth factor I enhances gonadotropin-releasing hormone-stimulated luteinizing hormone release from bovine anterior pituitary cells. Animal Reproduction Science 70 13-21.
Hasler JF, Bilby CR, Collier RJ, Denham SC \& Lucy MC 2003 Effect of recombinant bovine somatotropin on superovulatory response and recipient pregnancy rates in a commercial embryo transfer program. Theriogenology 59 1919-1928.

Henricks DM, Kouba AJ, Lackey BR, Boone WR \& Gray SL 1998 Identification of insulin-like growth factor I in bovine seminal plasma and its receptor on spermatozoa: influence on sperm motility. Biology of Reproduction 59 330-337.

Hernandez-Fonseca HJ, Sirisathien S, Bosch P, Cho HS, Lott JD, Hawkins LL, Hollet RB, Coley SL \& Brackett BG 2002 Offspring resulting from direct transfer of cryopreserved bovine embryos produced in vitro in chemically defined media. Animal Reproduction Science 69 151-158.

Herrler A, Lucas-Hahn A \& Niemann H 1992 Effects of insulin-like growth factor-1 on in-vitro production of bovine embryos. Theriogenology 37 1213-1224.

Herrler A, Einspanier R, Schams D \& Niemann H 1994 Effect of recombinant bovine somatotropin (rBST) on follicular IGF-I contents and the ovarian response following superovulatory treatment in dairy cows: a preliminary study. Theriogenology 41 601-611.

Herrler A, Krusche CA \& Beier HM 1998 Insulin and insulin-like growth factor-I promote rabbit blastocyst development and prevent apoptosis. Biology of Reproduction 59 1302-1310.

Hoeflich A, Reichenbach HD, Schwartz J, Grupp T, Weber MM, Foll J \& Wolf E 1999 Insulin-like growth factors and IGF-binding proteins in bovine seminal plasma. Domestic Animal Endocrinology 17 39-51.

Homburg R, Pariente C, Lunenfeld B \& Jacobs HS 1992 The role of insulinlike growth factor-1 (IGF-1) and the IGF binding protein-1 (IGFBP-1) in the pathogenesis of polycystic ovary syndrome. Human Reproduction 7 1379-1383.

Hu C-L, Cowan RG, Harman RM \& Quirk SM 2004 Cell cycle progression and activation of Akt kinase are required for insulin-like growth factor 1-mediated suppression of apoptosis in granulosa cells. Molecular Endocrinology 18 326-338.

Hwa V, Oh Y \& Rosenfeld RG 1999 The insulin-like growth factor-binding protein (IGFBP) superfamily. Endocrine Reviews 20 761-787.

Idris Anas M-K, Elmileik A, Maeda T \& Terada T 1998 Effects of epidermal growth factor, insulin like growth factor- 1 and insulin on meiotic maturation of bovine denuded oocytes. Journal of Mammalian Ova Research 15 179-184.

Iga K, Niwa K \& Bartke A 1998 Possible involvement of insulin-like growth factor 1 in mediating the stimulatory effect of recombinant bovine growth hormone on maturation of bovine oocytes in vitro. Journal of Reproduction and Development 44 243-251.

Ireland J, Ward F, Jimenez-Krassel F, Ireland JLH, Smith GW, Lonergan P \& Evans ACO 2007 Follicle numbers are highly repeatable within individual animals but are inversely correlated with FSH concentrations and the proportion of good-quality embryos after ovarian stimulation in cattle. Human Reproduction 22 1678-1695.

Irving-Rodgers H, Catanzariti KD, Master M, Grant PA, Owens PC \& Rodgers RJ 2003 Insulin-like growth factor binding proteins in follicular fluid from morphologically distinct healthy and atretic bovine antral follicles. Reproduction, Fertility, and Development 15 241-248.

Itoh T, Masayuki K, Hiroyuki A, Sendai Y \& Hoshi H 2002 Growth, antrum formation, and estradiol production of bovine preantral follicles cultured in a serum-free medium. Biology of Reproduction 67 1099-1105.

Jones JI \& Clemmons DR 1995 Insulin-like growth factors and their binding proteins: biological actions. Endocrine Reviews 16 3-34.

Jousan FD \& Hansen PJ 2004 Insulin-like growth factor-I as a survival factor for the bovine preimplantation embryo exposed to heat shock. Biology of Reproduction 71 1665-1670.

Jousan FD \& Hansen PJ 2007 Insulin-like growth factor-1 promotes resistance of bovine preimplantation embryos to heat shock through actions independent of its anti-apoptotic actions requiring $\mathrm{PI} 3 \mathrm{~K}$ signaling. Molecular Reproduction and Development 74 189-196.

Jousan FD, Oliveira LJ \& Hansen PJ 2008 Short-term culture of in vitro produced bovine preimplantation embryos with insulin-like growth factor-I prevents heat shock-induced apoptosis through activation of the phosphatidylinositol 3-kinase/Akt pathway. Molecular Reproduction and Development 75 681-688.

Juul A 2003 Serum levels of insulin-like growth factor I and its binding proteins in health and disease. Growth Hormone and IGF Research 13 113-170. 
Kadakia R, Arraztoa JA, Bondy C \& Zhou J 2001 Granulosa cell proliferation is impaired in the Igf1 null ovary. Growth Hormone and IGF Research 11 220-224.

Kadokawa H, Tameoka N, Uchiza M, Kimura Y \& Yonai M 2008 Short communication: a field study on the relationship between body condition and embryo production in superovulated Holstein yearling heifers. Journal of Dairy Science 91 1087-1091.

Kaiser GG, Sinowatz F \& Palma GA 2001 Effects of growth hormone on female reproductive organs. Anatomia, Histologia, Embryologia 30 265-271.

Kakar MA, Maddocks S, Lorimer MF, Kleemann DO \& Walker SK 2005 Insulin-like growth factor-1 concentrations in oviduct fluid of superovulated ewes during the periovular period. Reproduction, Fertility, and Development 17313 (abstract).

Kanitz W, Becker F, Schneider F, Kanitz E, Leidig C, Nohner HP \& Pohland R 2002 Superovulation in cattle: practical aspects of gonadotropin treatment and insemination. Reproduction, Nutrition, Development 42 587-599.

Kanuya N, Callesen H, Hyttel P, Assey R \& Greve T 1997 Superovulatory response of dairy cattle (Bos taurus) in a tropical environment. Theriogenology 47 1583-1593.

Kasimanickam R, Duffield TF, Foster RA, Gartley CJ, Leslie KE, Walton JS \& Johnson WH 2004 Endometrial cytology and ultrasonography for the detection of subclinical endometritis in postpartum dairy cows. Theriogenology 62 9-23.

Katagiri S \& Takahashi Y 2004 Changes in EGF concentrations during estrous cycle in bovine endometrium and their alterations in repeat breeder cows. Theriogenology 62 103-112.

Katagiri S, Moon YS \& Yuen BH 1996 The role for the uterine insulin-like gowth factor I in early embryonic loss after superovulation in the rat. Fertility and Sterility 65 426-436.

Katagiri S, Ma S, Yuen BH \& Moon YS 1997a Role for the insulin-like growth factor $\mathrm{I}$ in the regulation of electrolyte composition of uterine luminal fluid. Journal of Reproduction and Fertility 109 115-120.

Katagiri S, Moon YS \& Yuen BH 1997b A somatostatin analogue decreases embryonic loss following superovulation in rats by normalizing insulinlike growth factor-I action in the uterus. Human Reproduction 12 671-676.

Kaye PL, Bell KL, Beebe LFS, Dunglison GF, Gardner HG \& Harvey MB 1992 Insulin and insulin-like growth factors (IGFs) in preimplantation development. Reproduction, Fertility, and Development 4 373-386.

Keay SD, Liversedge NH, Akande VA, Mathur RS \& Jenkins JM 2003 Serum IGF-1 concentrations following pituitary desensitization do not predict the ovarian response to gonadotrophin stimulation prior to IVF. Human Reproduction 18 1797-1801.

Khamsi F, Roberge S, Yavas Y, Lacanna IC, Zhu X \& Wong J 2001a Recent discoveries in physiology of insulin-like growth factor-1 and its interaction with gonadotropins in folliculogenesis. Endocrine 16 151-165.

Khamsi F, Roberge S \& Wong J 2001b Novel demonstration of a physiologic/pharmacologic role of insulin-like growth factor-1 in ovulation in rats and action on cumulus oophorus. Endocrine 14 175-180.

Killian GJ 2004 Evidence for the role of oviduct secretions in sperm function, fertilization and embryo development. Animal Reproduction Science 82-83 141-153.

Kirby CJ, Armstrong JD, Huff BG, Stanko RL, Harvey RW, Heimer EP \& Campbell RM 1993 Changes in serum somatotropin, somatotropin mRNA, and serum and follicular insulin-like growth factor-I in response to feed restriction in cows actively immunized against growth hormonereleasing factor. Journal of Animal Science 71 3033-3042.

Kojima FN, Bergfeld EGM, Wehrman ME, Cupp AS, Fike KE, MariscalAguayo DV, Sanchez-Torres T, Garcia-Winder M, Clopton DT, Roberts AJ et al. 2003 Frequency of luteinizing hormone pulses in cattle influences duration of persistence of dominant ovarian follicles, follicular fluid concentrations of steroids, and activity of insulin-like growth factor binding proteins. Animal Reproduction Science 77 187-211.

Kowalik A, Liu H-C, He Z-Y, Mele C, Barmat L \& Rosenwaks Z 1999 Expression of the insulin-like growth factor-1 gene and its receptor in preimplantation mouse embryos; is it a marker of embryo viability? Molecular Human Reproduction 5 861-865.
Krysiak R, Okopień B, Gdula-Dymek A \& Herman ZS 2006 Update on the management of polycystic ovary syndrome. Pharmacological Reports $\mathbf{5 8}$ 614-625.

Kuehner LF, Rieger D, Walton JS, Zhao X \& Johnson WH 1993 The effect of a depot injection of recombinant bovine somatotropin on follicular development and embryo yield in superovulated Holstein heifers. Theriogenology 40 1003-1013.

Kurzawa R, Glabowski W, Baczkowski T \& Brelik P 2002 Evaluation of mouse preimplantation embryos exposed to oxidative stress cultured with insulin-like growth factor I and II, epidermal growth factor, insulin, transferrin and selenium. Reproductive Biology 2 143-162.

Kurzawa R, Glabowski W, Baczkowski T, Wiszniewska B \& Marchlewicz M 2004 Growth factors protect in vitro cultured embryos from the consequences of oxidative stress. Zygote 12 231-240.

Lackey BR, Boone WR, Gray SL \& Henricks DM 1998 Computer-assisted sperm motion analysis of bovine sperm treated with insulin-like growth factor I and II: implications as motility regulators and chemokinetic factors. Archives of Andrology 41 115-125.

Laron Z 2001 Insulin-like growth factor 1 (IGF-1): a growth hormone. Journal of Clinical Pathology: Molecular Pathology 54 311-316.

Lauria A, Genazzani AR, Oliva O, Inaudi P, Cremonesi F, Monittola C \& Aureli G 1982 Clinical and endocrinological investigations on superovulation induced in heifers by human menopausal gonadotrophin. Journal of Reproduction and Fertility 66 219-225.

Lazzari G, Wrenzycki C, Herrmann D, Duchi R, Kruip T, Niemann H \& Galli C 2002 Cellular and molecular deviations in bovine in vitroproduced embryos are related to the large offspring syndrome. Biology of Reproduction 67 767-775.

Lee ES \& Fukui Y 1995 Effect of various growth factors in a defined culture medium on in vitro development of bovine embryos matured and fertilized in vitro. Theriogenology 44 71-83.

van de Leemput EE, van der Hem A, Sprang EPM, Vos PLAM \& Dieleman SJ 1997 Do insulin-like growth factors play a role in final follicular maturation: superovulation as a test model. Theriogenology 49204 (abstract).

Leese HJ 2002 Quiet please, do not disturb: a hypothesis of embryo metabolism and viability. BioEssays 24 845-849.

Leese HJ 2003 What does an embryo need? Human Fertility 6 180-185.

Leese HJ, Sturmey RG, Baumann CG \& McEvoy TG 2007 Embryo viability and metabolism: obeying the quiet rules. Human Reproduction 22 3047-3050.

van Lier E, Meikle A, Eriksson H \& Sahlin L 2006 Insulin-like growth factor-I (IGF-I) and thioredoxin are differentially expressed along the reproductive tract of the ewe during the oestrous cycle and after ovariectomy. Acta Veterinaria Scandinavica 485.

Lima PF, Oliveira LA, Santos MH, Reichenbach HD, Weppert M, PaulaLopes FF, Neto CC \& Goncalves PB 2006 Effect of retinoids and growth factor on in vitro bovine embryos produced under chemically defined conditions. Animal Reproduction Science 95 184-192.

Lin TC, Yen JM, Gong KB, Hsu TT \& Chen LR 2003 IGF-1/IGFBP-1 increases blastocyst formation and total blastocyst cell number in mouse embryo culture and facilitates the establishment of a stem-cell line. BMC Cell Biology 414.

Lindsey BR, Maclellan LJ, Whyte TR, Kinder JE \& D'Occhio MJ 2002 Differential requirement for pulsatile $\mathrm{LH}$ during the follicular phase and exposure to the preovulatory LH surge for oocyte fertilization and embryo development in cattle. Theriogenology 58 1651-1662.

Liu JP, Baker J, Perkins AS, Robertson EJ \& Efstratiadis A 1993 Mice carrying null mutations of the genes encoding insulin-like growth factor I (Igf-1) and type 1 IGF receptor (Igfr). Cell 75 59-72.

Liu HC, He ZY, Mele CA, Veeck LL, Davis OK \& Rosenwaks Z 1997 Expression of IGFs and their receptors is a potential marker for embryo quality. American Journal of Reproductive Immunology 38 237-245.

Lonergan P, Gutierrez-Adan A, Pintado B, Fair T, Ward F, Fuente JD \& Boland M 2000 Relationship between time of first cleavage and the expression of IGF-I growth factor, its receptor, and two housekeeping genes in bovine two-cell embryos and blastocysts produced in vitro. Molecular Reproduction and Development 57 146-152.

Lonergan P, Rizos D, Gutierrez-Adan A, Moreira PM, Pintado B, de la Fuente J \& Boland MP 2003 Temporal divergence in the pattern of 
messenger RNA expression in bovine embryos cultured from the zygote to blastocyst stage in vitro or in vivo. Biology of Reproduction 69 1424-1431.

Lorenzo PL, Illera MJ, Illera JC \& Illera M 1994 Enhancement of cumulus expansion and nuclear maturation during bovine oocyte maturation in vitro by the addition of epidermal growth factor and insulin-like growth factor I. Journal of Reproduction and Fertility 101 697-701.

Lorenzo PL, Illera MJ, Illera JC \& Illera M 1995 Role of EGF, IGF-I, sera and cumulus cells on maturation in vitro of bovine oocytes. Theriogenology 44 109-118.

Lucy MC 2000 Regulation of ovarian follicular growth by somatotropin and insulin-like growth factors in cattle. Journal of Dairy Science $\mathbf{8 3}$ 1635-1647.

Makarevich AV \& Markkula M 2002 Apoptosis and cell proliferation potential of bovine embryos stimulated with insulin-like growth factor I during in vitro maturation and culture. Biology of Reproduction 66 386-392.

Makarevich AV \& Sirotkin AV 1997 The involvement of the GH/IGF-I axis in the regulation of secretory activity by bovine oviduct epithelial cells. Animal Reproduction Science 48 197-207.

Malhi PS, Adams GP \& Singh J 2005 Bovine model for the study of reproductive aging in women: follicular, luteal and endocrine characteristics. Biology of Reproduction 73 45-53.

Malhi PS, Adams GP, Pierson RA \& Singh J 2006 Bovine model of reproductive aging: response to ovarian synchronization and superstimulation. Theriogenology 66 1257-1266.

Mapletoft RJ, Steward KB \& Adams GP 2002 Recent advances in the superovulation in cattle. Reproduction, Nutrition, Development 42 601-611.

Mapletoft RJ, BÓ GA \& Adams GP 2006 Superovulation in the cow: effects of gonadotrophins and follicular wave status. Journal of Reproduction and Development 52 S7-S18.

Matsui M, Takahashi Y, Hishinuma M \& Kanagawa H 1997 Stimulation of the development of bovine embryos by insulin and insulin-like growth factor-I (IGF-I) is mediated through the IGF-1 receptor. Theriogenology 48 605-616.

Mazerbourg S, Bondy CA, Zhou J \& Monget P 2003 The insulin-like growth factor system: a key determinant role in the growth and selection of ovarian follicles? a comparative species study Reproduction in Domestic Animals 38 247-258.

McCaffery FH, Leask R, Riley SC \& Telfer EE 2000 Culture of bovine preantral follicles in a serum-free system: markers for assessment of growth and development. Biology of Reproduction 63 267-273.

McCusker RH 1998 Controlling insulin-like growth factor activity and the modulation of insulin-like growth factor binding protein and receptor binding. Journal of Dairy Science 81 1790-1800.

Meikle A, Sahlin L, Ferraris A, Masironi B, Blanc JE, Rodríguez-Irazoqui M, Rodríguez-Piñon M, Kindahl H \& Forsberg M 2001 Endometrial mRNA expression of oestrogen receptor alpha, progesterone receptor and insulin-like growth factor-I (IGF-I) throughout the bovine oestrous cycle. Animal Reproduction Science 68 45-56.

Ménézo YVR \& Hérubel F 2002 Mouse and bovine models for human IVF. Reproductive Biomedicine Online 4 170-175.

Mihm M \& Austin EJ 2002 The final stages of dominant follicle selection in cattle. Domestic Animal Endocrinology 23 155-166.

Mikkelsen AL 2005 Strategies in human in-vitro maturation and their clinical outcome. Reproductive Biomedicine Online 10 593-599.

Miyamoto A, Shirasuna K, Hayashi KG, Kamada D, Awashima C, Kaneko E, Acosta TJ \& Matsui M 2006 A potential use of color ultrasound as a tool for reproductive management: new observations using color ultrasound scanning that were not possible with imaging only in black and white. Journal of Reproduction and Development 52 153-160.

Moley KH, Bibee K, Wyman A \& Eng GS 2005 IGF-1 induced blastocyst apoptosis is p53 dependant. Fertility and Sterility $\mathbf{8 4}$ S388 (abstract).

Monget P \& Bondy C 2000 Importance of the IGF system in early folliculogenesis. Molecular and Cellular Endocrinology 163 89-93.

Monget P \& Martin GB 1997 Involvement of insulin-like growth factors in the interactions between nutrition and reproduction in female mammals. Human Reproduction 12 33-52.
Moore K, Kramer JM, Rodriguez-Sallaberry CJ, Yelich JV \& Drost M 2007 Insulin-like growth factor (IGF) family genes are aberrantly expressed in bovine conceptuses produced in vitro or by nuclear transfer. Theriogenology 68 717-727.

Moreira F, Paula-Lopes FF, Hansen PJ, Badinga L \& Thatcher WW 2002a Effects of growth hormone and insulin-like growth factor-I on development of in vitro derived bovine embryos. Theriogenology $\mathbf{5 7}$ 895-907.

Moreira F, Badinga L, Burnley C \& Thatcher WW 2002b Bovine somatotropin increases embryonic development in superovulated cows and improves post-transfer pregnancy rates when given to lactating recipient cows. Theriogenology 57 1371-1387.

Moyano P \& Rotwein P 2004 Mini-review: estrogen action in the uterus and insulin-like growth factor-I. Growth Hormone and IGF Research 14 431-435.

Murphy LJ, Murphy LC \& Friesen HG 1987 Estrogen induces insulin-like growth factor-I expression in the rat uterus. Molecular Endocrinology $\mathbf{1}$ 445-450.

Nardo LG, Bellanca SA, Burrello N, Longo G, D'Agata R, Nardo F \& Calogero AE 2001 Concentrations of insulin-like growth factor (IGF)-I and IGF binding protein-3 in the follicular fluid of women undergoing ovarian hyperstimulation with different gonadotropin preparations. Gynecological Endocrinology 15 413-420.

Neves EF, Ramos AF \& Marques Júnior AP 2005 Pre-treatment with bovine somatotropin (rbST) in the superovulation of Holstein donors. Arquivo Brasileiro de Medicina Veterinaria e Zootechnia 57 205-209.

Nicholas B, Scougall RK, Armstrong DG \& Webb R 2002 Changes in insulin-like growth factor binding protein (IGFBP) isoforms during bovine follicular development. Reproduction 124 439-446.

Nicholas B, Alberio R, Fouladi-Nashta AA \& Webb R 2005 Relationship between low-molecular-weight insulin-like growth factor-binding proteins, caspase- 3 activity, and oocyte quality. Biology of Reproduction $72796-804$.

Niemann H \& Wrenzycki C 2000 Alterations of expression of developmentally important genes in preimplantation bovine embryos by in vitro culture conditions: implications for subsequent development. Theriogenology $5321-34$.

Nix JP, Spitzer JC \& Chenoweth PJ 1998 Serum testosterone concentration, efficiency of estrus detection and libido expression in androgenized beef cows. Theriogenology 49 1195-1207.

Norman RJ, Dewailly D, Legro RS \& Hickey TE 2007 Polycystic ovary syndrome. Lancet 370 685-697.

Nuttinck F, Charpigny G, Mermillod P, Loosfelt H, Meduri G, Freret S, Grimard B \& Heyman Y 2004 Expression of components of the insulinlike growth factor system and gonadotropin receptors in bovine cumulus-oocyte complexes during oocyte maturation. Domestic Animal Endocrinology 27 179-195.

O'Callaghan D, Yaakub H, Hyttel P, Spicer LJ \& Boland MP 2000 Effect of nutrition and superovulation on oocyte morphology, follicular fluid composition and systemic hormone concentrations in ewes. Journal of Reproduction and Fertility 118 303-313.

Oropeza A, Wrenzycki C, Herrmann D, Hadeler K-G \& Niemann H 2004 Improvement of the developmental capacity of oocytes from prepubertal cattle by intraovarian insulin-like growth factor-I application. Biology of Reproduction 70 1634-1643.

Oropeza A, Hadeler K-G \& Niemann H 2006 Application of ultrasoundguided follicular aspiration (OPU) in prepubertal and adult cattle. Journal of Reproduction and Development 52 S31-S38.

Ortega HH, Palomar MM, Acosta JC, Salvetti NR, Dallard BE, Lorente JA, Barbeito CG \& Gimeno EJ 2008 Insulin-like growth factor I in sera, ovarian follicles and follicular fluid of cows with spontaneous or induced cystic ovarian disease. Research in Veterinary Science 84 419-427.

Otoi T, Yamamoto K, Koyama N, Tachikawa S \& Suzuki T 1997 Bovine oocyte diameter in relation to developmental competence. Theriogenology 48 769-774.

Palomba S, Oppedisano R, Tolino A, Orio F \& Zullo F 2008 Outlook: metformin use in infertile patients with polycystic ovary syndrome: an evidence-based overview. Reproductive Biomedicine Online 16 327-335.

Palma GA, Muller M \& Brem G 1997 Effect of insulin-like growth factor-I (IGF-I) at high concentrations on blastocyst development of bovine embryos produced in vitro. Journal of Reproduction and Fertility $\mathbf{1 1 0}$ 347-353. 
Peixoto MGCD, Fonseca CG, Penna VM \& Alvim MTT 2002 Multivariate analysis of multiple ovulation followed by embryo transfer results from zebu donors. Arquivo Brasileiro de Medicina Veterinária e Zootechnia 54 492-500.

Pérez-Martínez C, García-Fernández RA, Escudero A, Ferreras MC \& García-Iglesias MJ 2001 Expression of cytokeratins and vimentin in normal and neoplastic tissue from the bovine female reproductive tract. Journal of Comparative Pathology 124 70-78.

Perks CM, Peters AR \& Wathes DC 1999 Follicular and luteal expression of insulin-like growth factors I and II and the type 1 IGF receptor in the bovine ovary. Journal of Reproduction and Fertility 116 157-165.

Pershing RA, Lucy MC, Thatcher WW \& Badinga L 2002 Effects of BST on oviductal and uterine genes encoding components of the IGF-1 system in lactating dairy cows. Journal of Dairy Science 85 3260-3267.

Pinto AB, Schlein AL \& Moley KH 2002 Preimplantation exposure to high insulin-like growth factor I concentrations results in increased resorption rates in vivo. Human Reproduction 17 457-462.

Poretsky L, Cataldo NA, Rosenwaks Z \& Giudice LC 1999 The insulinrelated ovarian regulatory system in health and disease. Endocrine Reviews 20 535-582.

Prelle K, Stojkovic M, Boxhammer K, Motlik J, Ewald D, Arnold GJ \& Wolf E 2001 Insulin-like growth factor I (IGF-I) and long R $^{3}$ IGF-I differently affect development and messenger ribonucleic acid abundance for IGF-binding proteins and type I IGF receptors in in vitro produced bovine embryos. Endocrinology 142 1309-1316.

Pushpakumara PGA, Robinson RS, Demmers KJ, Mann GE, Sinclair KD, Webb R \& Wathes DC 2002 Expression of the insulin-like growth factor (IGF) system in the bovine oviduct at oestrus and during early pregnancy. Reproduction 123 859-868.

Quetglas MD, Coelho LA, Garcia JM, Oliveira Filho EB \& Esper CR 2001 Effect of insulin-like growth factor-1 during in vitro oocyte maturation and in vitro culture of bovine embryos. Arquivo Brasileiro de Medicina Veterinaria e Zootechnia 53 1-5.

Quirk SM, Harman RM \& Cowan RG 2000 Regulation of Fas antigen (Fas, CD95)-mediated apoptosis of bovine granulosa cells by serum and growth factors. Biology of Reproduction 63 1278-1284.

Rajamahendran R, Ambrose DJ \& Burton B 1994 Clinical and research applications of real-time ultrasonography in bovine reproduction: a review. Canadian Veterinary Journal 35 563-572.

Reiling BA, Drackley JK, Grum LR \& Berger LL 1997 Effects of prenatal androgenization and lactation on adipose tissue metabolism in finishing single-calf heifers. Journal of Animal Science 75 1504-1513.

Reinhardt RR \& Bondy CA 1994 Insulin-like growth factors cross the bloodbrain barrier. Endocrinology 135 1753-1761.

Rhodes FM, Peterson AJ \& Jolly PD 2001 Gonadotrophin responsiveness, aromatase activity and insulin-like growth factor binding protein content of bovine ovarian follicles during the first follicular wave. Reproduction 122 561-569.

Ribadu AY \& Nakao T 1999 Bovine reproductive ultrasonography: a review. Journal of Reproduction and Development 45 13-28.

Richards MW, Wettemann RP, Spicer LJ \& Morgan GL 1991 Nutritional anestrus in beef cows: effects of body condition and ovariectomy on serum luteinizing hormone and insulin-like growth factor-l. Biology of Reproduction 44 961-966.

Rieger D, Walton JS, Goodwin ML \& Johnson WH 1991 The effect of co-treatment with recombinant bovine somatotrophin on plasma progesterone concentration and number of embryos collected from superovulated Holstein heifers. Theriogenology 35 863-868.

Rieger D, Luciano AM, Modina S, Pocar P, Lauria A \& Gandolfi F 1998 The effects of epidermal growth factor and insulin-like growth factor I on the metabolic activity, nuclear maturation and subsequent development of cattle oocytes in vitro. Journal of Reproduction and Fertility 112 123-130.

Rinderknecht E \& Humbel RE 1976a Polypeptides with nonsuppressible insulin-like and cell-growth-promoting activities in human serum: isolation, chemical characterization, and some biological properties of forms I and II. PNAS 73 2365-2369.

Rinderknecht E \& Humbel RE $1976 b$ Amino-terminal sequences of two polypeptides from human serum with nonsuppressible insulin-like and cell-growth-promoting activities: evidence for structural homology with insulin B chain. PNAS 73 4379-4381.
Rivera GM \& Fortune JE 2001 Development of codominant follicles in cattle is associated with a follicle-stimulating hormone-dependent insulin-like growth factor binding protein-4 protease. Biology of Reproduction 65 112-118.

Rivera GM \& Fortune JE 2003 Proteolysis of insulin-like growth factor binding proteins -4 and -5 in bovine follicular fluid: implications for ovarian follicular selection and dominance. Endocrinology 144 2977-2987.

Robinson RS, Mann GE, Gadd TS, Lamming GE \& Wathes DC 2000 The expression of the IGF system in the bovine uterus throughout the oestrous cycle and early pregnancy. Journal of Endocrinology 165 231-243.

De Roover R, Bols PEJ, Genicot G \& Hanzen CH 2005 Characterisation of low, medium and high responders following $\mathrm{FSH}$ stimulation prior to ultrasound-guided transvaginal oocyte retrieval in cows. Theriogenology 63 1902-1913.

Rosenfeld RG, Hwa V \& Youngman O 2001 Nomenclature of the insulinlike growth factor-binding protein superfamily. Journal of Clinical Endocrinology and Metabolism 86946.

Sahlin L, Norstedt G \& Eriksson H 1994 Estrogen regulation of the estrogen receptor and insulinlike growth factor-I in the rat uterus: a potential coupling between effects of estrogen and IGF-1. Steroids 59 421-430.

Sakaguchi M, Dominko T, Leibfried-Rutledge ML, Nagai T \& First NL 2000 A combination of EGF and IGF-1 accelerates the progression of meiosis in bovine follicular oocytes and fetal calf serum neutralizes the acceleration effect. Theriogenology 54 1327-1342.

Sakaguchi M, Dominko T, Yamauchi N, Leibfried-Rutledge ML, Nagai T \& First NL 2002 Possible mechanism for acceleration of meiotic progression of bovine follicular oocytes by growth factors in vitro. Reproduction 123 135-142.

Salmon WD Jr \& Daughaday WH 1956 Sulfation factor, a serum component mediating the action of growth hormone in stimulating incorporation of sulfate into cartilage. Journal of Clinical Investigation 35733 (abstract).

Salmon WD Jr \& Daughaday WH 1957 A hormonally controlled serum factor which stimulates sulfate incorporation by cartilage in vitro. Journal of Laboratory and Clinical Medicine 149 825-836.

Santiago CA, Voge JL, Aad PY, Allen DT, Stein DR, Malayer JR \& Spicer LJ 2005 Pregnancy-associates plasma protein-A and insulin-like growth factor binding protein mRNAs in granulosa cells of dominant and subordinate follicles of preovulatory cattle. Domestic Animal Endocrinology 28 46-63.

Sawai K, Kageyama S, Moriyasu S, Hirayama H, Minamihashi A \& Onoe S 2005 Analysis of mRNA transcripts for insulin-like growth factor receptors and binding proteins in bovine embryos derived from somatic cell nuclear transfer. Cloning and Stem Cells 7 189-198.

Sawai K, Kageyama S, Moriyasu S, Hirayama H, Minamihashi A \& Onoe S 2007 Changes in the mRNA transcripts of insulin-like growth factor ligand, receptors, and binding proteins in bovine blastocysts and elongated embryos derived from somatic cell nuclear transfer. Journal of Reproduction and Development 53 77-86.

Scaramuzzi RJ, Murray JF, Downing JA \& Campbell BK 1999 The effects of exogenous growth hormone on follicular steroid secretion and ovulation rate in sheep. Domestic Animal Endocrinology 17 269-277.

Schams D, Berisha B, Kosmann M \& Amselgruber WM 2002 Expression and localization of IGF family members in bovine antral follicles during final growth and luteal tissue during different stages of estrous cycle and pregnancy. Domestic Animal Endocrinology 22 51-72.

Schernhammer ES 2002 In-utero exposures and breast cancer risk: joint effect of estrogens and insulin-like growth factor? Cancer Causes \& Control 13 505-508.

Schmidt A, Einspanier R, Amselgruber W, Sinowatz F \& Schams D 1994 Expression of insulin-like growth factor 1 (IGF-1) in the bovine oviduct during the oestrous cycle. Experimental and Clinical Endocrinology 102 364-369.

Schoyer KD, Liu HC, Witkin S, Rosenwaks Z \& Spandorfer SD 2007 Serum insulin-like growth factor I (IGF-I) and IGF-binding protein 3 (IGFBP-3) in IVF patients with polycystic ovary syndrome: correlations with outcome. Fertility and Sterility 88 139-144.

Schultz GA, Hogan A, Watson AJ, Smith RM \& Heyner S 1992 Insulin, insulin-like growth factors and glucose transporters: temporal patterns of gene expression in early murine and bovine embryos. Reproduction, Fertility, and Development 4 361-371. 
Shingo AS \& Kito S 2003 Estrogen induces insulin-like growth factor-1 mRNA expression in the immortalized hippocampal cell: determination by quantitative real-time polymerase chain reaction. Neurochemical Research 28 1379-1383.

Siddiqui MAR, Shamsuddin M, Bhuiyan MMU, Akbar MA \& Kamaruddin KM 2002 Effect of feeding and body condition score on multiple ovulation and embryo production in zebu cows. Reproduction in Domestic Animals 37 37-41.

Simmen RC, Simmen FA, Hofig A, Farmer SJ \& Bazer FW 1990 Hormonal regulation of insulin-like growth factor gene expression in pig uterus. Endocrinology 127 2166-2174.

Simmen RCM, Ko Y \& Simmen FA 1993 Insulin-like growth factors and blastocyst development. Theriogenology 39 163-175.

Simpson RB, Chase CCJr, Spicer LJ, Vernon RK, Hammond AC \& Rae DO 1994 Effect of exogenous insulin on plasma and follicular insulin-like growth factor I, insulin-like growth factor binding protein activity, follicular oestradiol and progesterone, and follicular growth in superovulated Angus and Brahman cows. Journal of Reproduction and Fertility 102 483-492.

Sinclair KD, Rooke JA \& McEvoy TG 2003 Regulation of nutrient uptake and metabolism in pre-elongation ruminant embryos. Reproduction $\mathbf{6 1}$ 371-385.

Singh KB 2005 Persistent estrus rat models of polycystic ovary disease: an update. Fertility and Sterility 84 (Supplement 2) 1228-1234.

Sirard M-A, Richard F, Blondin P \& Robert C 2006 Contribution of the oocyte to embryo quality. Theriogenology 65 126-136.

Sirisathien S \& Brackett BG 2003 TUNEL analyses of bovine blastocyst after culture with EGF and IGF-1. Molecular Reproduction and Development 65 51-56.

Sirisathien S, Hernandez-Fonseca HJ \& Brackett BG 2003 Influences of epidermal growth factor and insulin-like growth factor-I on bovine blastocyst development in vitro. Animal Reproduction Science 77 21-32.

Sirotkin AV 2005 Control of reproductive processes by growth hormone: extra- and intracellular mechanisms. Veterinary Journal 170 307-317.

De La Sota RL, Lucy MC, Staples CR \& Thatcher WW 1993 Effects of recombinant bovine somatotropin (sometribove) on ovarian function in lactating and nonlactating dairy cows. Journal of Dairy Science $\mathbf{7 6}$ 1002-1013.

de la Sota RL, Simmen FA, Diaz T \& Thatcher WW 1996 Insulin-like growth factor system in bovine first-wave dominant and subordinate follicles. Biology of Reproduction 55 803-812.

Spicer LJ 2004 Proteolytic degradation of insulin-like growth factor binding proteins by ovarian follicles: a control mechanism for selection of dominant follicles. Biology of Reproduction 70 1223-1230.

Spicer LJ \& Aad PY 2007 Insulin-like growth factor (IGF) 2 stimulates steroidogenesis and mitosis of bovine granulosa cells through the IGF-1 receptor: role of follicle-stimulating hormone and IGF2 receptor. Biology of Reproduction 77 18-27.

Spicer LJ \& Echternkamp SE 1995 The ovarian insulin and insulin-like growth factor system with emphasis on domestic animals. Domestic Animal Endocrinology 12 223-245.

Spicer LJ, Enright WJ, Murphy MG \& Roche JF 1991 Effect of dietary intake on concentrations of insulin-like growth factor-I in plasma and follicular fluid, and ovarian function in heifers. Domestic Animal Endocrinology 8 431-437.

Spicer LJ, Crowe MA, Prendiville DJ, Goulding D \& Enright WJ 1992 Systemic but not intraovarian concentrations of insulin-like growth factor-I are affected by short-term fasting. Biology of Reproduction $\mathbf{4 6}$ 920-925.

Spicer LJ, Alpizar E \& Echternkamp SE 1993 Effects of insulin, insulin-like growth factor I, and gonadotropins on bovine granulosa cell proliferation, progesterone production, estradiol production, and (or) insulinlike growth factor I production in vitro. Journal of Animal Science $\mathbf{7 1}$ 1232-1241.

Spicer LJ, Alvarez P, Prado TM, Morgan GL \& Hamilton TD 2000 Effects of intraovarian infusion of insulin-like growth factor-I on ovarian follicular function in cattle. Domestic Animal Endocrinology 18 265-278.

Spicer LJ, Chamberlain CS \& Morgan GL 2001 Proteolysis of insulin-like growth factor binding proteins during preovulatory follicular development in cattle. Domestic Animal Endocrinology 21 1-15.
Spicer LJ, Chamberlain CS \& Maciel SM 2002 Influence of gonadotropins on insulin- and insulin-like growth factor-I (IGF-I)-induced steroid production by bovine granulosa cells. Domestic Animal Endocrinology 22 237-254.

Spicer LJ, Voge JL \& Allen DT 2004 Insulin-like growth factor-II stimulates steroidogenesis in cultured bovine thecal cells. Molecular and Cellular Endocrinology 227 1-7.

Staigmiller RB, Bellows RA, Anderson GB, Seidel GE Jr, Foote WD, Menino AR Jr \& Wright RW Jr 1992 Superovulation of cattle with equine pituitary extract and porcine FSH. Theriogenology 37 1091-1099.

Stefanello JR, Barreta MH, Porciuncula PM, Arruda JN, Oliveira JF, Oliveira MA \& Gonçalves PB 2006 Effect of angiotensin II with follicle cells and insulin-like growth factor-I or insulin on bovine oocyte maturation and embryo development. Theriogenology $\mathbf{6 6}$ 2068-2076.

Stewart RE, Spicer LJ, Hamilton DT \& Keefer BE 1995 Effects of insulin-like growth factor I and insulin on proliferation and on basal luteinizing hormone-induced steroidogenesis of bovine theca cells: involvement of glucose and receptors for insulin-like growth factor I and luteinizing hormone. Journal of Animal Science 73 3719-3731.

Stewart RE, Spicer LJ, Hamilton DT, Keefer BE, Dawson LJ, Morgan GL \& Echternkamp SE 1996 Levels of insulin-like growth factor (IGF) binding proteins, luteinizing hormone and IGF-I receptors, and steroids in dominant follicles during the first follicular wave in cattle exhibiting regular estrous cycles. Endocrinology 137 2842-2850.

Stroud B \& Hasler JF 2006 Dissecting why superovulation and embryo transfer usually work on some farms but not in others. Theriogenology $\mathbf{6 5}$ 65-76

Sudo N, Shimizu T, Kawashima C, Kaneko E, Tetsuka M \& Miyamoto A 2007 Insulin-like growth factor-I (IGF-I) system during follicle development in the bovine ovary: relationship among IGF-I, type 1 IGF receptor (IGFR-1) and pregnancy-associated plasma protein-A (PAPP-A). Molecular and Cellular Endocrinology 264 197-203.

Suzuki A, Urushitani H, Watanabe H, Sato T, Iguchi T, Kobayashi T \& Ohta Y 2007 Comparison of estrogen responsive genes in the mouse uterus, vagina and mammary gland. Journal of Veterinary Medical Science 69 725-731.

Szukiewicz D \& Uilenbroek JTL 1998 Polycystic ovary syndrome searching for an animal model. Journal of Medicine 29 259-275.

Takagi M, Kim IH, Izadyar F, Hyttel P, Bevers MM, Dieleman SJ, Hendriksen PJ \& Vos PL 2001 Impaired final follicular maturation in heifers after superovulation with recombinant human FSH. Reproduction 121 941-951.

Thomas FH, Campbell BK, Armstrong DG \& Telfer EE 2007 Effects of IGF-1 bioavailability on bovine preantral follicular development in vitro. Reproduction 133 1121-1128.

Todoroki J \& Kaneko H 2006 Formation of follicular cysts in cattle and therapeutic effects of controlled internal drug release. Journal of Reproduction and Development 52 1-11.

Todoroki J, Noguchi J, Kikuchi K \& Kaneko H 2004 Retrospective analysis of the efficacy of controlled internal drug release in follicular cysts in an embryo donor beef herd. Journal of Reproduction and Development $\mathbf{5 0}$ 369-373.

Tosca L, Chabrolle C, Uzbecova S \& Dupont J 2007 Effects of metformin on bovine granulose cells steroidogenesis: possible involment of adenosine $5^{\prime}$ monophosphate-activated protein kinase (AMPK). Biology of Reproduction 76 368-378.

Tummon I, Gavrilova-Jordan L, Allemand MC \& Session D 2005 Polycystic ovaries and ovarian hyperstimulation syndrome: a systematic review. Acta Obstetricia et Gynecologica Scandinavica 84 611-616.

Veiga-Lopez A, Gonzales-Bulnes A, Garcia-Garcia RM, Dominguez V \& Cocero MJ 2005 The effects of previous ovarian status on ovulation rate and early embryo development in response to superovularoty FSH treatments in sheep. Theriogenology 63 1973-1983.

Velazquez MA 2008 Assisted reproductive technologies in cattle: applications in livestock production, biomedical research and conservation biology. Annual Review of Biomedical Sciences 10 36-62.

Velazquez MA, Dobson H, Smith RF, Cripps PJ, Crowe MA, Newman M \& Christie MF 2004 Hormonal and metabolic profiles as an indicator of embryo production from donors and pregnancy outcome in recipients in 
MOET programmes: preliminary results. Proceedings of the 15th International Congress on Animal Reproduction, Porto Seguro, Brazil, vol 2. Abstract 401.

Velazquez MA, Newman M, Christie MF, Cripps PJ, Crowe MA, Smith RF \& Dobson H 2005 The usefulness of a single measurement of insulin-like growth factor-1 as a predictor of embryo yield and pregnancy rates in a bovine MOET program. Theriogenology 64 1977-1994.

Velazquez MA, Spicer LJ \& Wathes DC 2008a The role of endocrine insulinlike growth factor-I (IGF-I) in female bovine reproduction. Domestic Animal Endocrinology 35 325-342.

Velazquez MA, Korsawe K \& Niemann H 2008b The effects of physiological and non-physiological insulin-like growth factor-1 (IGF-1) concentrations on the in vitro development of bovine embryos. Reproduction in Domestic Animals 43202 (abstract 530).

Vendola K, Zhou J, Wang J \& Bondy CA 1999 Androgens promote insulinlike growth factor-I and insulin-like growth factor-I receptor gene expression in the primate ovary. Human Reproduction 14 2328-2332.

Viuff D, Hyttel P, Greve T, Eriksen T \& Alexandersen S 1995 Transcription and localization of growth factor mRNA in the bovine oviduct. Molecular Reproduction and Development 42 28-34.

Walters KA, Binnie JP, Campbell BK, Armstrong DG \& Telfer EE 2006 The effects of IGF-1 on bovine follicle development and IGFBP-2 expression are dose and stage dependent. Reproduction 131 515-523.

Wang T-H, Chang C-L, Wu H-M, Chiu Y-M, Chen C-K \& Wang H-S 2006 Insulin-like growth factor-II (IGF-II), IGF-binding proteins-3 (IGFBP-3), and IGFBP-4 in follicular fluid are associated with oocyte maturation and embryo development. Fertility and Sterility 86 1392-1401.

Warzych E, Wrenzycki C, Peippo J \& Lechniak D 2007 Maturation medium supplements affect transcript level of apoptosis and cell survival related genes in bovine blastocyst produced in vitro. Molecular Reproduction and Development $\mathbf{7 4}$ 280-289.

Wasielak M \& Bogacki M 2007 Apoptosis inhibition by insulin-like growth factor (IGF)-I during in vitro maturation of bovine oocytes. Journal of Reproduction and Development 53 419-426.

Wathes DC, Reynolds TS, Robinson RS \& Stevenson KR 1998 Role of the insulin-like growth factor system in uterine function and placental development in ruminants. Journal of Dairy Science 81 1778-1789.

Wathes DC, Taylor VJ \& Cheng Z 2001 Metabolic interactions with fertility. Cattle Practice 9 291-296.

Wathes DC, Taylor VJ, Cheng Z \& Mann GE 2003 Follicle growth, corpus luteum function and their effects on embryo development in postpartum dairy cows. Reproduction 61 219-237.

Watson AJ, Hogan A, Hahnel A, Wiemer KE \& Schultz GA 1992 Expression of growth factor ligand and receptor genes in the preimplantation bovine embryo. Molecular Reproduction and Development 31 87-95.

Watson AJ, Westhusin ME \& Winger QA 1999 IGF paracrine and autocrine interactions between conceptus and oviduct. Journal of Reproduction and Fertility $\mathbf{5 4}$ 303-315.

Webb R \& Campbell BK 2007 Development of the dominant follicle: mechanisms of selection and maintenance of oocyte quality. Society of Reproduction and Fertility 64 141-163.

Webb R, Nicholas B, Gong JG, Campbell BK, Gutierrez CG, Garverick HA \& Armstrong DG 2003 Mechanisms regulating follicular development and selection of the dominant follicle. Reproduction 61 71-90.

Webb R, Garnsworthy PC, Gong J-G \& Armstrong DG 2004 Control of follicular growth: local interactions and nutritional influences. Journal of Animal Science 82 E63-E74.

Webber LJ, Stubbs S, Stark J, Trew GH, Margara R, Hardy K \& Franks S 2003 Formation and early development of follicles in the polycystic ovary. Lancet 362 1017-1021.

Wetscher F, Havlicek V, Huber T, Gilles M, Tesfaye D, Griese J, Wimmers K, Schellander K, Müller M, Brem G et al. 2005 Intrafallopian transfer of gametes and early stage embryos for in vivo culture in cattle. Theriogenology 64 30-40.
Willemsen D, Palma GA \& Wolf E 1995 Vitrification of in-vitro produced bovine embryos after culture in medium supplemented with insulin-like growth factor-I (IGF-I). Theriogenology 43352 (abstract).

Wilson JM, Jones AL, Moore K, Looney CR \& Bondioli KR 1993 Superovulation of cattle with a recombinant-DNA bovine follicle stimualting hormone. Animal Reproduction Science 33 71-82.

Winger QA, de los Rios P, Han VKM, Armstrong DT, Hill DJ \& Watson AJ 1997 Bovine oviductal and embryonic insulin-like growth factor binding proteins: possible regulators of 'embryotrophic' insulin-like growth factor circuits. Biology of Reproduction 56 1415-1423.

Wolf E, Arnold GJ, Bauersachs S, Beier HM, Blum H, Einspanier R, Fröhlich T, Herrler A, Hiendleder S, Kölle S et al. 2003 Embryo-maternal communication in bovine - strategies for deciphering a complex crosstalk. Reproduction in Domestic Animals 38 276-289.

Wrenzycki C, Herrmann D, Lucas-Hahn A, Gebert C, Korsawe K, Lemme E, Carnwath JW \& Niemann H 2005 Epigenetic reprogramming throughout preimplantation development and consequences for assisted reproductive technologies. Birth Defects Research. Part C, Embryo Today 75 1-9.

Wrenzycki C, Herrmann D \& Niemann H 2007 Messenger RNA in oocytes and embryos in relation to embryo viability. Theriogenology 68 S77-S83.

Xia P, Han VKM, Viuff D, Armstrong DT \& Watson AJ 1996 Expression of insulin-like growth factors in two bovine oviductal cultures employed for embryo co-culture. Journal of Endocrinology 149 41-53.

Yaakub H, O'Callaghan D \& Boland MP 1999 Effect of type and quantity of concentrates on superovulation and embryo yield in beef heifers. Theriogenology 51 1259-1266.

Yang MY \& Rajamahendran R 1998 Effects of gonadotropins and insulin-like growth factors-I and -II on in vitro steroid production by bovine granulosa cells. Canadian Journal of Animal Science 78 587-597.

Yang MY \& Rajamahendran R 2000 Morphological and biochemical identification of apoptosis in small, medium, and large bovine follicles and the effects of follicle-stimulating hormone and insulin-like growth factor-1 on spontaneous apoptosis in cultured bovine granulosa cells. Biology of Reproduction 62 1209-1217.

Yaseen MA, Wrenzycki C, Herrmann D, Carnwath JW \& Niemann H 2001 Changes in the relative abundance of mRNA transcripts for insulin-like growth factor (IGF-I and IGF-II) ligands and their receptors (IGF-IR/IGFIIR) in preimplantation bovine embryos derived from different in vitro systems. Reproduction 122 601-610.

Yoshida Y, Miyamura M, Hamano S \& Yoshida M 1998 Expression of growth factor ligand and their receptor mRNAs in bovine ova during in vitro maturation and after fertilization in vitro. Journal of Veterinary Medical Science 60 549-554.

Yu Y, Li W, Han Z, Luo M, Chang Z \& Tan J 2003 The effect of folliclestimulating hormone on follicular development, granulose cells apoptosis and steroidogenesis and its mediation by insulin-like growth factor-I in the goat ovary. Theriogenology 60 1961-1704.

Zhou J, Kumar TR, Matzuk MM \& Bondy C 1997 Insulin-like growth factor-I regulates gonadotropin responsiveness in the murine ovary. Molecular Endocrinology 11 1924-1933.

Zulu VC, Nakao T \& Sawamukai Y 2002 Insulin-like growth factor-1 as a possible mediator of nutritional regulation of reproduction in cattle. Journal of Veterinary Medical Science 64 657-665.

Received 21 August 2008

First decision 8 October 2008

Accepted 21 November 2008 